\title{
The Large Deep-Seated Landslide Induced by the March 12th, 2012 Rainfall Event in the City of Azazga, Northern Algeria: Deformation Characteristics and Failure Mechanisms
}

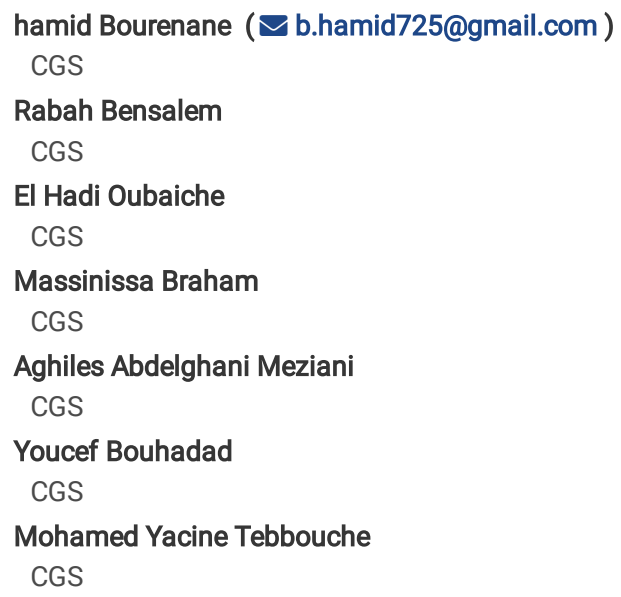




\section{Abstract}

A rainfall-induced deep large landslide occurred on March 12, 2012, in the city of Azazga (northern Algeria) causing heavy damages to residential buildings and public infrastructures. In this work, we investigate the inventory mapping, deformation characteristics, the controlling factors and the failure mechanisms of this landslide based on field investigation, aerial photographs/satellite images interpretation, deep boreholes equipped with piezometers and inclinometers as well as subsurface geophysical imaging by Electric Resistivity Tomography (ERT). The obtained landslide inventory map shows that the landslide of March 2012 , affected an area of $0,40 \mathrm{~km}^{2}$. This landslide is considered as partial reactivations of large pre-existing one $\left(0,606 \mathrm{~km}^{2}\right)$ which represents $6,65 \%$ of the total urban area. Moreover, the analyses identified two types of involved causative factors: (i) the triggering factor related to the antecedent rainfall and human activity through slope excavations and embankment; $\quad$ (ii) susceptibility factors related to the lithological nature and the internal structure of the flysch deposits, their weak mechanical resistance characteristics, the presence of shallow aquifers, steep slope and basal erosion and undercutting of the lazoughen and Aboud rivers torrents. The inclinometers measurements and ERT imaging reveal a complex, deep-seated and rapidly moving landslide whose failure surfaces located at the depth of 11 to $28 \mathrm{~m}$ and an average velocity of 1 to $28 \mathrm{~cm}$ yr-1 with a displacement in the Northwest direction toward the Aboud and lazoughen rivers. The entire slip surface is located along the geotechnical interface between the flyschs bedrock and the overlying scree. This comprehensive study provides a useful information of rainfall-induced landslides as well as guidance for landslide hazard mitigation and prevention.

\section{Introduction}

Rainfall induced landslides are among the most recurrent and damaging geological hazards that cause substantial negative consequences in the northern of Algeria, especially, in urban areas. They constitute a serious threat for human lives and their properties and a major constraint for the economic development and urban planning of many cities of the country. Landslides occur often during rainy seasons particularly during torrential rainstorms recorded between October and April (Riheb et al. 2012; Djerbal et al., 2012; Bourenane et al. 2014; Bourenane et al. 2016; Bourenane 2017; Bourenane et al., 2019; Bourenane and Bouhadad 2020). The impact of these land instabilities is often exacerbated by the rapid demographic growth, the rapid uncontrolled development of the urbanization in landslide-prone areas and the heavy rainfall trend (Bourenane et al., 2016; Bourenane et al., 2019; Bourenane and Bouhadad 2020).

The city of Azazga situated in the mountainous province of Grande Kabylia in north of Algeria, is one of the most affected urban area by recurrent and widespread landslides (Djerbal et al., 2012). The occurrence and the frequency of the landslides is related to the interaction between natural susceptibility factors and triggering mechanisms. Landslide triggering factors include, amongst others, well-known mechanisms such as, rainfall duration and intensity, snow melting and human activity. Landslide susceptibility factors include the geological structures, the mechanical properties of the bedrock, the local geomorphic, topographic, and the tectonic controls. Therefore, the deformation mechanisms of rainfall-induced landslides are complex, due to several geomorphological and climatic settings as well as human activities.

The active landslides of the Azazga city are alarming because of their localization in urban environment with high density of population, their great extension by involving several hectares of slope land and the serious damage to dwellings and public infrastructures. The landslide occurrence has been largely triggered by frequent extreme rainfall events related to exceptional climatic conditions (heavy rain or snow) especially in the rainy season between December to February. Recently the frequency of landslide occurrences in Azazga increased significantly following heavy rainfalls. Indeed, the urban area is experiencing, according to the available historical data, an intense activity of landslides since winter 1952 causing serious damage to buildings and infrastructures. Hence, rainfall-induced large landslides represent a persistent and permanent threat to settlements and infrastructures becoming, hence, a major obstacle for future urban development during the last decade.

A series of severe rainfall events that triggered larges landslides caused huge damage in the urban area of Azazga. The most historical cases occurred in 1952, 1973, 1952, 1955, 1973, 1974, 1984, 2003, 2004, 2012, 2014, 2018 and 2019 (Le Temps d'Algérie, Algerian daily newspaper, March 11th 2012; El Watan, Algerian daily newspaper, November 28th 2018; Liberté, Algerian daily newspaper, Jannuary, 17th 2019; CGS, 2010, CGS, 2018) are caused and reactivated by heavy rainfall during the winter season causing substantial damage to several constructions and roads in Ighil Bouzel, Agouni Guizem, Aït Bouhouni, Tizi Bouchen, Tala- Oukouchah and Tadart districts as well as sensible infrastructures such as the hospital, the polyclinic, the cultural center, the Azazga technical high school, the municipal roads and the national roads RN 71 and RN 12 (Fig. 2a). These occurrences give ample evidence on the susceptibility of the region for landslides caused by rainfall. Such landslides may cause huge economic losses by destroying constructions and infrastructures and may be the direct cause of losses of human lives. Long duration and high intensity rainfall episodes are identified as major triggering factors: short and intense rainfall often generates shallow landslides, with slope deformation in the surface (Michiue 1985; Dai and Lee 2001). In contrast, prolonged, low intensity rainfall mostly triggered deep-seated landslides with the sliding surface is located at deeper weak layers that leads to large bedding rockslides and colluvial landslides (Hong et al. 2005).

The heavy rainfall and snowfall of March 2012 triggered and reactivated various types of landslides such as rock fall, rock slide, debris slide and debris flow within several sites of the urban area of Azazga such as Tala Oukouchah, Zen and Ighil- Bouzel in the north and Agouni- Guizem and Aït Bouhouni in the south (Fig. 1). The slope movements have caused damage to roads, settlements of houses and public infrastructures over an area of about $2 \mathrm{~km}^{2}$. The total landslides triggered by the March $12^{\text {th }}, 2012$ rainfall event was reported (see the Fig. 2a).

The Ighil Bouzel landslide is one of the most damaging and largest active landslide that affected the vicinity of Ighil Bouzel village in north of the city of Azazga. It is occurred on March 11, 2012 at 3:00 am following the heavy rainfall that started in early February. The landslide induced ground deformation extensively observed in the most susceptible areas around Tala- Oukouchah and Ighil Bouzel villages, mainly along the lazoughen river where, the geological, geotechnical, and hydrogeological conditions are the most favorable. The landslide occur along a slope with an average slope of $15^{\circ}$, in a S-N direction including, from upstream to downstream, the districts of Tadart, Ighil Bouzel, Tala Oukouchah and Zen (Fig. 2a). This deep-seated landslide has been known 
since 1970s as one of the fastest and largest landslide and are still evolving. During the disaster, the extremely unstable slope of the post-slide deposits still threatens the human lives and properties of the local residents.

The Ighil Bouzel landslide constitute the great concern and represents an important risk and then a high-priority scientific challenge because of his location in urban areas with high population density, his large extension and the extent of the disorders in the affected constructions, infrastructures, roads and water supply pipes causing high risk conditions for the population. The landslide was largely reported by the national and local medias and also by local residents as can be viewed on videos at (https://www.youtube.com/watch?v=Kj440Cui-6Y,https://www.youtube.com/watch? v =cJmpXv1E4X4). As a consequence, this gravitational slope had a considerable impact and a continuous threat on the villages of Ighil Bouzel, Tadart, Tala Oukouchah and Zen. The landslide will constitutes a grave threat to the security of human lives and properties if efficient technical measures are not implemented to control its continuous movement.

Actually, the frequency and the impact of the landslide hazard are still exacerbated by: (i) environmental mismanagement and a lack of rules and regulations; (ii) the absence of a mitigation and management prevention policy of the risk; (iii) the accelerated and unplanned urbanization in the unstable zones and (iv) lack of investment in the comprehension of the hazard and risk related to landslides. The progression of the landslides and their alarming consequences that constitute a major risk to human lives and properties as well as a constant constraint to urban planning and extension that urged the need for in-depth study of cases landslides for hazard mitigation and prevention. Faced to the importance of the increasing risks in Azazga region there has been no efforts to explore these events and to take them into consideration in slope management and land use planning. The authorities are stressing and alerted about the lack of knowledge of the landslides, their identification, their causal factors, their failure mechanisms and evolution process in order to reduce and prevent the risk related to potential landslides and to take them into account in development and urban planning projects.

Understanding the landslides characteristics as well as their causative mechanisms and evolution is a real challenge for scientists and a vitally important for prediction, monitoring and controlling of landslide occurrence and also for providing helpful informations for choosing landslide hazard mitigation measures and prevention (e.g., Dai et al., 2002; Chau et al., 2004; Harp et al., 2011; Dai et al., 2011; Guzzetti et al., 2012). For this, many scientists for many years have tried to study and understand the characteristics of landslides, their kinematics as well as their triggering factors and evolution.

In this study, we investigate the inventory mapping, deformation characteristics, influencing factors, failure mechanisms and we discuss the possible mitigation measures of the large rainfall-induced landslides around the Ighil Bouzel village located in the city of Azazga, northern Algeria. For this purpose, the adopted methodology include multi-parameter observational data based on the field surveys, photo interpretation, and exploitation of the available geotechnical and geophysical investigations data such as deep boreholes equipped with piezometers and inclinometers, laboratory tests and electric resistivity tomography (ERT) imaging. This exhaustive study provides insights into rainfall-induced landslides, as well as guidance for the reduction and prevention of landslide hazard and risk.

\section{Description of the study area}

The landslide occurred in Ighil Bouzel village is situated in north of the city of Azazga (northern Algeria) along the left bank of the lazoughen river (Fig. 2a), at about $135 \mathrm{~km}$ east of the Algerian capital, Algiers (Fig. 2b), and about $35 \mathrm{~km}$ east of Tizi-Ouzou prefecture (Wilaya). Oriented north-east-south-west, the affected area is an ancient landslide with an extremely wide distribution effects area. The unstable site is located within the urban zone perimeter and defined by its geographical coordinates: latitude $36.749^{\circ} \mathrm{N}$ and longitude $4.371^{\circ} \mathrm{E}$.

Geomorphologically, this important landslide, belongs to the massif of Grande Kabylia, in the north part of the Tellean Atlas chain. The unstable zone is a hilly area located on the foothill of the El Abed Mountain with a slope dipping north at an angle of 10 to $20^{\circ}$ (Fig. 2a). The upper slope is relatively gentler than the lower part. The landslide head scarp appeared at the market place in the city center near the national road RN 12 at an elevation of $450 \mathrm{~m}$ (above sea level), and the landslide toe is at an elevation of $330 \mathrm{~m}$ near the converges zone between the Aboud and lazoughen rivers. The slope deformations are presented in form of specific morphology or structures (from the upper to the lower part of the slope); scarps, counterscarps, crests and double crests, are confirmations of deep-seated landslide deformation that affects hundreds of meters along the lazoughen river. This geomorphology is strongly influenced by the variety and distribution of the outcropping lithology, tectonics activity, hydrography network and erosion processes.

The main geological structure of the area belonging to the North-Kabyle Flyschs domain located in the internal zones of the Maghrebides chain (Fig. 3). The study area is built on Cretaceous-Oligocene flysch bedrock that consists of thick-bedded complexes of clay and marl formations, largely outcropping on the surface above a thick series of Numidian clays and sandstones forming the main landforms to the east and covered by quaternary scree deposits to the north (Gelard, 1979; National Office of Geological and Mining Research ORGM, 1996). These formations which cover a large surface of the urban area of Azazga city, are affected by numerous crack faults and very sensitive to the presence of water with high plasticity, consequently susceptible to erosions, landslides, rockslide and flows. Tectonically, landslides are located in the flyschs area, an allochthonous domain, characterized by thrust sheets that have been displaced during or after their sedimentation during the alpine tectonic phase. The main tectonic features include (Gelard, 1979; ORGM, 1997): (Fig. 3) (i) A major tectonic contact, oriented N-S separating the "flysch of Azazga" unit and the Numidian unit; (ii) A system of faults in two main directions SW-NE and NW-SE, visible particularly in the Numidian sandstones and (iii) The over thrust of Numidian sandstones on Cretaceous clay to the west. In addition, the highly altered and fractured nature of the substrate involves a major role of meteorological water infiltration (precipitation, snowmelt) which affects the equilibrium state of the slope. The faults, located in the upper part of the slide, act and participate in the deceleration and evolution of the slide speed. Waters from precipitation and snowmelt infiltrate within the altered body and along the main faults and cracks until they reach the permanent stream identified at the toe of the landslide

The Azazga region is highly prone to rainfall-induced landslides occurrences due to its climatic conditions "Mediterranean type" characterized by the high intensity of precipitation (700 to $1200 \mathrm{~mm} \mathrm{yr}-1$ ) over a short period during rainy season extending from December to Mars that represents 50 to $60 \%$ of the 
yearly precipitation (Bourenane et al., 2019; Bourenane and Bouhadad 2020).

From the hydrological point of view, NW-SE oriented Aboud, lazoughen and Boulina rivers developed on both sides of the landslide with a semi-permanent flow that are associated to temporary flow affluent waterways (Figs.2 and 3). The hydrogeology of the area is largely controlled by the distribution of the permeable quaternary scree and impermeable flyschs stratum of clay and marl (Fig.3). The upper layer is relatively permeable and allows water to pass through, whereas the underlying shale stratum could be considered impermeable. The groundwater of the slope is principally replenished by precipitations through surface seepage and fluctuates seasonally with rainfall. So the groundwater resources is significant, particularly during the winter period (December to February) when rainfall is at its highest (high water period). Therefore, the groundwater level of the landslide increases during the winter season, with most of the water runoff and discharge tracing the steep slope in a S-N direction towards the lower toe. Some of the groundwater is discharged as spring water in a low depression at the back margin of the landslide and other seeps at the foot of the steep slope at the front edge of the landslide (Fig. 2).

The study area is developed in inappropriate land use, in forest and agricultural zones that leads to more frequent landslides. These different features provide favorable geomorphic conditions for the slope failure.

\section{Data And Methodology}

\subsection{Database preparation}

In order to investigate in more detail the internal structures, the failure mechanism, the deformation characteristics and the fundamental controls factors of the rainfall induced landslide on March $12^{\text {th }}, 2012$ in the northern of Azazga city, the available in situ investigations geological, geotechnical, and hydrogeological data, carried out by several companies in the framework of several construction project studies have been compiled, analyzed and processed. These data were integrated in a database (called Azazga_Data_Base and Géo_Map) under GIS framework using MS. Access, Surfer 18 and Arc GIS 9 which allowed easy a spatial analysis, exploiting, processing and managing of such large amount of data in the same local projection system of Algeria (Northern UTM the Sahara; WGS 1984; spindle 31 North). The prepared database includes (Fig. 4):

- Rainfall database covering a period of 64 years from the 03 meteorological stations "Azazga Ecole, Yakourene and Freha" monitored by the National Agency of Water Resources (ANRH, 2019) is compiled and analyzed in order to investigate and outline the rainfall conditions of the study area and mainly the intensity of rainfall that triggered the March 2012 landslide event including the timing of the slope failures,. The data set comprised the list of daily measured rainfall starting from 1950. The location of meteorological stations (rain gauges) are shown in figure 2a;

- Geological and geotechnical investigations data of the study area carried out by several companies (LCTP, 2012-2014; CGS, 2018) have been compiled, analyzed and processed in order to investigate the geological structure and the geotechnical characteristics of the landslide and potential slide surfaces. The reconnaissance campaign data include:

(i) The geological data such as lithology, bedrock and tectonic structure obtained from the digitization of the published geological map at a scale of 1:50,000 by the National Office of Geological and Mining Research (ORGM, 1997);

(ii) Eighteen (18) boreholes of depth ranging between 30 and $36 \mathrm{~m}$ among them twelve (12) boreholes equipped with piezometers (BP), six (06) boreholes equipped with inclinometers (BI), as well as twenty (20) laboratory tests (grain size distribution, liquidity limit $\mathrm{LL}$, and plasticity limit PL) of selected samples in subsoil layers carried out by the National Laboratory of Public Works (L.C.T.P, 2012 and 2014) as part of geotechnical investigation in a framework of a land use plan studies (POS).

- The geophysical investigation data consist of Electrical Resistivity Tomography - ERT measurements carried out by CGS in the landslide area, in January 2020. These reconnaissance programs also provided an opportunity to investigate in more detail the internal structures of the landslides and the failure mechanism based on the distribution of electrical resistivity contrasts of the soil. To better understand the material structure and failure mechanism, several 1:1000-scale profiles were drawn to show the material and thickness of each layer and failure surfaces of landslides according to the site-specific investigation;

- The hydrogeological data concern the inventory of the 65 existing water points (4 springs and 61 wells) throughout the study area conducted by the National Center of Research in Earthquake Engineering (CGS) in April 2014, 2015 and 2017 for the high water period. The locations of boreholes, water points and the position of cross-sections are shown in figure 4;

- The topographic digital data obtained from a digital elevation model (DEM) with $10 \mathrm{~m}$ resolution obtained by the digitization of topographic maps at a scale of 1:25,000 provided by the Institute of Cartography and Remote Sensing (INCT). Then the DEM is used to extract topographical parameters (e.g., elevation, slope gradient and aspect) using GIS. The hydrographic network, roads, and other basic geographical data were also digitized from the topographic maps, high-resolution satellite imagery Alsat 2A (taken in 2011) completed by our geological field work investigations.

\subsection{Landslide inventory mapping}

Following the March 2012 rainfall events we executed field investigations to identify and map the rainfall induced landslides. The detailed active landslide is mapped in ArcGIS at a scale of 1:10 000 based on: (i) the analysis and interpretation of aerial photographs at different scales: $1 / 20,000,1 / 10,000$ and $1 / 4,000$ taken, respectively in 1973, 1984, 2000 and 2008 respectively. These aerial photographs are provided by the Algerian institute of cartography and remote sensing (INCT); (ii) the analysis and interpretation of recent high resolution ( $2.5 \mathrm{~m}$ ) Alsat images taken in $2011 \mathrm{from}$ the Algerian Space Agency (ASAL); (iii) the analysis of Google Earth satellite images from 2003 to 2012, with a spatial resolution of 15 m; (iv) analysis of DEM (10-m resolution) generated by digitization and kriging interpolation of elevation lines extracted from topographic map at a scale of 1:25,000 scale provided by the Algerian 
institute of cartography and remote sensing (INCT); (iv) analysis of archive documents and available data (technical reports of LTPC, 1986 and 1976; LCTP, 2012 and 2014; CGS, 2010 and 2018) completed by (v) field surveys.

\subsection{Field observations}

The first field observation of the site was carried out one day after the slope failure (March 11, 2012). Supplementary and extensive field investigations were carried out between 2012 and 2019 targeting the landslides area in order to :(i) verify and validate the inventory map made from aerial photographs and satellite images interpretation; (ii) investigate the geological conditions of slopes (e.g., the structural type of slope, lithology, bedrock lithology...); (iii) identify the geomorphological features (typology of landslide, topography, deformation characteristics, type of material involved in slope failures, map landslide extent, boundaries and state of activity) as well as the geometrical parameters (such as hillslope gradients, the perimeter and the maximal length) of the landslides; (iii) investigate possible landslide causal factors; (iv) failure mechanism and (v) describe the extent of damage induced by the triggered slope failures. The boundary of each deformation zone, position, length, and width of cracks, and damaged structures were determined, recorded and mapped on satellite images.

Field reconnaissance was also necessary to: (i) verify landslides whose area and the boundaries that could not be clearly identified from the aerial photographs and satellite image interpretation by using field indices such as Leaning lamp posts, trees and walls, semicircular cracks in land and roads (caused by the head scarp back-stepping); (ii) identify the physical processes that govern the landslide activity; (iii) inspection of the influence of lithological units, on landslide; (iv) investigate the characteristics of slope, lithologies, land use and their relations in more details (v) understanding of land use practices (changes in vegetation, agricultural practices involving tillage and deep-ploughing, urbanization with modifications of natural morphology) as an important causal factor of instability. The characteristic features of the landslid, including head- and side scarps, dip-slip and strike-slip striate, bowl shaped head areas caused by multiple rotational slides, hummocky shape areas, tension cracks, and ponding areas. After fieldwork, the landslide inventory was refined and updated with the gathered observations.

\section{Results}

\subsection{The March 2012 rainfall event}

Rainfall is the major triggering factor identified and monitored at the study site. Water infiltration in the shallow geological deposits has a strong mechanical effect on the dissolution and alteration of the subsurface material and can reach deeper through fractures.

It is known that high intensity rainfall are rare events which trigger landslides and induce significant morphological changes to a large area. A "rainfall event" corresponds to a group of rainy days preceded and followed by at least one (1) day with no rain. Azazga, is one of the most watered regions of Algeria with its Mediterranean climate is exposed to intense and variable meteorological episodes. The frequency and intensity of the rainfall is mainly concentrated from December to February. The average annual rainfall recorded at the "Azazga ecole" meteorological station located at a distance of about $1 \mathrm{~km}$ from the area affected by the movements (Fig. 2) for the period between 1950 and 2014 is 974 mm, with a minimum in 2001 (521 mm) and a maximum in 2002 (1536 $\mathrm{mm})$. The highest daily value is $125 \mathrm{~mm}$, which was registered on 6 December 2001. The rainfall mainly concentrates in the period from December to March and accounts for more than $50 \%$ of the annual rainfall amount. The more relevant rainfall events are measured in the fall period (December to February), and especially in December.

Analysis of these data showed clearly the great variability and irregularity of the inter-annual rains and their exceptional concentration during a given period. The most historical slope movements recorded in the city of Azazga (1952, 1955, 1973, 1974, 1984, 2003, 2004, 2012 and 2014) are linked to heavy rainfall eventS that exceeded $900 \mathrm{~mm}$. These movements were particularly triggered between December and March for average rainfall exceeding $500 \mathrm{~mm}$.

During the period extending between March $1^{\text {st }}$ to $12^{\text {th }}, 2012$ Azazga CITY and its surrounding areas in Kabylia experienced heavy rainfall. The unusual high rainfall triggered large number of landslides. The month of March, which corresponds to the end of a winter and the beginning of the spring seasons is known, generally moderate rainfall with occasional localized heavy rainfall in the mountainous regions of the Kabylia. The high-intensity rainfall accompanied by important snow that characterized the winter of 2012 had triggered and reactivated several field instabilities in Algeria.

During the 2011 - 2012 winter season (December- February), diffuse rainfall hit the Azazga region with 564 mm of precipitation recorded in "Azazga ecole" station that represents $55 \%$ of the total rainfall of the year of 2012. Furthermore, from early spring of 2012 the same area has been affected by a series of consecutive rainfall events. On March $12^{\text {th }}, 2012$ a heavy rainstorm was recorded in Azazga region and triggered several landslides where the registered 24hour rainfall at "Azazga ecole" rain gauge station exceeded $19.6 \mathrm{~mm}$. Since January 2012 the estimated precipitations are $262 \mathrm{~mm}$ (January), $232 \mathrm{~mm}$ (February), $127 \mathrm{~mm}$ (March) with $56.5 \mathrm{~mm}$ recorded between 1 to 12 March. Cumulative peak rainfall over these three months reached $691 \mathrm{~mm}$ in 2012 (Fig. 5), which represents $65 \%$ of the annual precipitations. The antecedent rainfall at that time could be the principal cause that induced the failure of the lghil Bouzel slope (Fig. 5). Figure 5 shows the cumulative rainfall between December to March for the last ten years recorded in the city of Azazga indicating that the accumulated rainfall from May to November represents about $80 \%$ of the total rainfall. The intensive rainfalls is concentrate in the period December March that led to the increase of groundwater level. It is obvious that a high accumulation of rainfall may be sufficient to trigger certain types of slope movements whereas for others type of landslides an exceptional climatic events are needed. The antecedent rainfall has influence the degree of saturation of the soil and consequently, plays an important role for the initiation of the landslides (Godt et al., 2006). Table 1 shows the maximum daily precipitation and antecedent rainfalls $(3,7,10$ and 15 days) registered during the period of March 2012 for the aforementioned rainstorm. The values are not very high but played an important role in the initiation of the landslides based on available rainfall records from rain stations installed close to the study area. Considering the series of rainfall data from 1 January 1950 and 12 March 2012 it is possible to know the periods during which the daily rainfall values were higher than those recorded in March $12^{\text {th }}, 2012$. These exceedance numbers could be considered as the rainfall values of the date of the beginning of the landslide. 


\subsection{Landslide inventory map}

The inventory map of the landslides zone has been prepared at a scale of 1:10,000 based on a combination of satellite imagery, aerial photographs completed by field investigations. The resulted landslide inventory map is presented as polygons in Arc- GIS and draped over a 10-m resolution ASTER-derived digital elevation model (DEM) and geology of the study area (Fig. 6). Figure 6 shows the map of the landslides and the geology of the active zone. The Ighil- Bouzel landslide map was performed based on the results of field surveys carried out immediately after the rainfall event of March, 2012. The ground deformations such as tension cracks, fissures, scarps, minor scarps and bulges as well as disturbed morphology of the clay and scree formations have contributed to a better identification of the unstable areas (Fig. 7). However, as the area is urbanized, the limits of the upstream part of the Ighil Bouzel landslide have been delineated on the basis of the observed damage in constructions, roadways and in the ground (Figs. 8, 9 and 10).

The obtained landslides perimeter of all actived zone covers an area of 0,606 $\mathrm{km}^{2}$ which represents $6,65 \%$ of the total urban area of Azazga (Figs. 6 and 10 ). The boundaries extend over approximately $1570 \mathrm{~m}$ length, between Tadart distict and the lazoughen river, and a width varying from 350 to $550 \mathrm{~m}$ (Figs. 6 and 10). With a mean depth of $18 \mathrm{~m}$, the estimated surface area of the landslide body is $852.5 \times 10^{4} \mathrm{~m}^{2}$ and the volume is around $153.45 \times 10^{5} \mathrm{~m}^{3}$. The height between the main scarp of the highest slide (Tadart market) and the lowest slide (river) is around $230 \mathrm{~m}$. According to the classification of Varnes (1978), the majority of the mapped slope instabilities can be grouped into slide types. The slides are the most significant in terms of the mobilized volumes and extents (several tens of hectares). They are very widespread in the scree formations and along the area between Aboud and lazoughen rivers (Fig. 6). They occur on $10^{\circ}$ to $15^{\circ}$ slopes and showed a disturbed morphology consisting of bulges, cracks, folds and slope breaks. These landslides are slow movements that can under heavy rainfall, evolve into sudden slides recognizable by the formation of head fractures (metric scale scarps) and dense traction cracks of varying depths and lengths. The landslide area is characterized by mottled topography with disturbed slope where the olive trees are inclined and with ground cracks of 1 to $3 \mathrm{~cm}$.

The mapped landslides present elongated shapes and tend to be channeled towards the lazoughen streams. Numerous mass movements display characteristics of reactivation as attested by the secondary landslide bodies existing inside them. In some cases, they are a partial reactivation of old landslides debris caused by stream erosion. These land instabilities are characterized by a main arched shape, scarp and morphological features typical of slide zones with the presence of hummocky topography and foot ridges indicating the evolution of the movement into the flow.

During the 2012 winter heavy rainfall and snowfall the accumulated precipitation reached $700 \mathrm{~mm}$ and many landslides have been occurred and/or reactivated. Landslide activity reaches its maximum during and just after the rainy events. Besides, runoffs related to snow melting and rain as well as infiltrations in the schistose texture marls, favored by the high permeability of fissured rocks, increased the interstitial pressure and make them less resistant to shear stresses that lead to gravitational movements. These instabilities caused damage to several public and private infrastructures. Many ground fissures were also generated and reactivated in different directions after the March 2012 rainfall event. They were quite continuously observed, along hundreds of meters, in the upstream and downstream part of the slope. It consist often on a set of an 'in echelon'-disposed fissures indicating in general a right-lateral displacement.

The Ighil Bouzel mass movements induced by the March $12^{\text {th }}, 2012$ rainfall event are located along the slope between the lazoughen and the Aboud river. Landslide affects mainly the scree over a length of $1000 \mathrm{~m}$ and a width of $550 \mathrm{~m}$ and covers a perimeter of $0,3922 \mathrm{~km}^{2}$. With a mean depth of $18 \mathrm{~m}$, the estimated surface area of the landslide body is $15.5 \times 10^{2} \mathrm{~m}^{2}$, the volume is around $27.9 \times 10^{3} \mathrm{~m}^{3}$. The unstable areas is presented in the form of an elongated catchment area where various sources of waters converged. The high humidity of the slope due to an abandoned drainage network, the discontinuity of the scree/substratum and the location of faults sometimes visible in the upstream part of the slope are probably the main factors of this landslides. Upstream, the slope is around $10^{\circ}$ while downstream the slope becomes steeper and remains marked by traces of recent activity such as distension and compression cracks as well as lateral and transverse compression ridges. Several springs, such as the Tala Oukouchah spring, coming from the Numidian sandstone lead to water spread in the clay-sand deposits. The faults that limit the entire upstream unstable zone are the preferred location for water infiltration at the head of the landslide. The landscape also presents an often-mottled morphology linked either to the solifluction or to slower, largerscale land movements. The shape and mode of sliding are probably controlled by the internal structure of the flysch bedrock dipping in the slope direction and the orientation of the schistose texture planes in the dip slope direction as well as the contact limit (interface) between basement and the flysch. The dense hydrographic network shows active erosion due to a relatively high rainfall (700 to $900 \mathrm{~mm} / \mathrm{year}$ ), that maintains the effective saturation of the soils and the fragile, clayey terrain. In addition, the down cutting erosion (regressive erosion) at the feet of slopes contribute to their destabilization.

\subsection{Deformation process and characteristics of the landslide induced by the March $12^{\text {th }}, 2012$ rainfall event}

\subsubsection{Characteristics of landslide event}

The rainfall-induced landslide is located in Ighil Bouzel village on the right bank of the lazoughen river, an ancient active zone with an extremely wide distribution area. It represents one of the most active landslides experienced by the region during recent years that have affected highly the urbanized area and caused damage to many constructions, roads and agriculture areas. The landslide is located along a versant with an average slope of $12^{\circ}$, along the Aboud river that converges towards the lazoughen river (Fig. 6). The urbanization of this slope started in early 1980 has led to an intense morphological change resulting from earthworks, constructions and roads opening. The historic inventory of these ground failures shows that rainfall is the main triggering factor. This land instability was known since February 1973, reactivated, respectively, in April 1974, in March 1985 and in March 2012 always following extended period of rainfalls that characterized the winter season. The most landslide-prone zones are located in the right bank of the lazoughen river and in the most urbanized zone of the Azazga city, as shown in Figure 9. The landslide surface present a significant number of tension cracks, scarps, minor scarps and bulges that developed gradually at the middle of the landslide. These deformations caused damage to some residential houses, roads, and public infrastructures. 
The Rainfall induced landslide of Ighil Bouzel corresponds to a large complex deep active landslide. The slope movement combine, upstream, characteristics of a rotational landslide (with two juxtaposed semi-circular scarps and two slightly down slope sectors downstream) and a characteristics of a translational landslide in the body of the landslide downstream. The slope of Ighil Bouzel has been sliding towards the lazoughen river, with active peaks of accelerated movement. Additionally, the very altered and fractured nature of the substratum implied a main role of meteorological water infiltration (rainfall, snow melt) affecting the equilibrium state of the slope. The section of the landslide is crossed in the middle and the head by the two important national roads RN 71 and RN12 and municipality ways (Fig. 4).

\subsubsection{Deformation characteristics based on field observations}

The landslide presents a particularly chaotic topography aspect and a significant series of scarps (most of which are the main scarps for minor landslides slide-flow), subsidence, transverse cracks, bulges parallel to the general slope and separated by cliffs. The landslide has experienced a long deformation history that was observed every year, particularly during the rainy season, showing a potentially highly activity area with a main scarp. Within the main landslides body have been observed arcuate main scarp (Fig. 7a) and minor scarps, fissuring, depressions, bulges, and minor landslides. Along the flank of the medium section of the landslide continuous shear surfaces with evident slickensides and lateral levees were observed (Fig. 7a, b, c, e, $f$ and $g$ ) as well as centimeter to several meters- long fissures and ground settlement along the Aboud and lazoughen waterways (Fig. 7c, $d$ and e). A gentle bulge in ground surface (Fig. 7c) frequently delineates landslide toe, sometime tongue shaped in plan. Landslide toe, often tongue shaped in plan, is subsiding with high slopes (Fig. 7h). Large cracking and ground cracks were induced in the middle and the toe part of the landslide, reaching a maximum length of $\sim 50 \mathrm{~m}$, a width of $\sim 50 \mathrm{~cm}$. The cracks are observed along the main national roads of RN 12 and RN 71 (Fig. $8 \mathrm{c}, \mathrm{e}, \mathrm{f}$, and h).

The landslide deformation intensified in the middle with a large number of ground fissures tension cracks were found with lengths extending from 1 to $50 \mathrm{~m}$, widths from 5 to $30 \mathrm{~cm}$ and vertical displacements of 10-60 cm. The activated landslides on March 2012 is considered as partial reactivations of pre-existing landslides deposits. Some of these landslides have experienced multiple reactivations, with also damages that manifested over the last decades.

The reactivation of the landslides was sensitive to torrential rainfall as the main triggering factor and the fragile geological structure with previous slope movement as the susceptibility factors. Under the action of rainfall, the slope gravity and the pore water pressure increased. Basal erosion by the river torrents the foot of the landslide area, markedly destabilizing the slopes. During rainstorms season, surface water penetrated into newly formed cracks, increasing the fragility of the soil. Meanwhile, the water content of materials increased, then cohesion loses and effective friction angle on sliding belt decreased noticeably on wetting state, and the stability of slopes was at limit equilibrium state. This leads to decreased resisting forces and increased sliding forces. In addition, the fragile geological structure contributed to the slide occurrence. These discontinuities favored the slide occurrence as water of rainfall penetrated into soil through these joint sets, while internal or external erosion can form new rupture surface and finally reactivated formed sliding surface. Thus, these conditions resulted in the reactivation of the Ighil Bouzel within a short time after heavy rainfall.

The in situ investigations conducted immediately following the landslide event showed that the natural surface drainage system seems to have increased the accumulation of water at the surface, sub-surface and even groundwater in some areas, as well as the collection and stagnation of large quantities of water, making the soils more susceptible to the landslides occurrence (Fig. $7 \mathrm{~h}$ ). Moreover, rainwater infiltrated through the tension cracks and reached the internal weak layer.

Based on morphology and deformation characteristics, the Ighil Bouzel landslide can be classified into two deformation zones: (i) the rear low deformation zone in upstream showing small deformation features, with some crakes and fissures were induced during the 2012 rainfall event. The elevation of the upstream area ranges between 440 to $500 \mathrm{~m}$, and the mean gradient is $10^{\circ}$. This area has a surface of $400 \times 470 \mathrm{~m}^{2}$ and (ii) the front high deformation zone in downstream (Figs. 7, 8, 9, 10, 14 and 12) with expanded, large, heavy and abundant deformations such as transverse cracks, bulges, tensile cracks and subsidence. The elevation of the downstream zone ranges between 320 to $420 \mathrm{~m}$, the mean slope is $20^{\circ}$ and the extent is approximately $1170 \times 550 \mathrm{~m}^{2}$.

\subsubsection{Damagebased on field observations}

After the slope failure, the landform topography had deformed significantly presenting a large number of ground fissures, cracks, a surface bulge that caused collapse of national roads, rural roads, residential houses and public infrastructures. The landslide began, with slight cracking starting to appear in the roads and around some of the houses in the head part of the landslide. Figs. 6, 7, 8 and 10 show the landslides and prepared damage map based on field surveys carried out immediately after the rainfall event of March 2012. The landslides caused damage to the provincial road, several private constructions and agriculture mainly in the upstream and middle portion of the landslide. Some residential buildings were also experiencing serious cracking, accompanied by noise, with the situation obviously deteriorating. In addition, the landslides caused indirect costs related to the many people evacuated for both short and long periods of time. Immediately after the event, 20 houses were formally evacuated, because either of structural damage suffered or as precautionary measure to avoid damage to people.

Several constructions exhibit cracks to total destabilization, two roads including the national roads RN 12 and RN 71 were deeply damaged and put out of traffic service (Fig. 8e, f, g, h). In total, ten houses were severely damaged in the villages of Tala Oukouchah, Zen and Ighil- Bouzel (Fig. 8c). The landslide induced large-scale damages with cracking of constructions and shear zones in columns, beams, load-bearing walls as well as tilting (Fig. 8c). The most significant damage affected the cultural centre (Fig. 8a), the stadium (Fig. 8b), dwellings, and water supply pipes (Fig. 7 d) that showed tilts (Fig. 8f), fissures and utility poles inclined (Fig. 8f). In addition, several other housing units suffered minor cracks.

\subsubsection{Field evidences of previous landslides}

The Ighil Bouzel landslide includes a series of unstable areas located along a slope with an average slope of $10^{\circ}$, oriented North-South towards the Aboud and lazoughen rivers. Many field observations in and around the landslides zone revealed the existence of previous evidences of instabilities and indicate that the 
landslides induced by the March 2012 rainfall event are partial reactivations of pre-existing landslides. Indeed, field observations showed steep to moderate slopes where the reliefs have a mottled morphology characteristic of low stability slopes with counter slopes, double crests, counterscarps, old scarps and long cliff-like scarps parallel to the general slope trend that are evidence of ancient movements as can be shown in Fig. 9. These are common forms of instabilities that have already functioned in past landslide still slowly evolving nowadays. This specific morphological feature is evidence of a deep-seated landslide affecting hundreds of meters along the lazoughen River (Fig. 9). (Fig. 10).

The area is affected by a series of successive rotational slides where the displaced materials show chaotic morphology characterized by a strongly hummocky topography with the bulges increasing in a downstream direction. Upstream, the slopes are gentler with scarp zones consisting of multiple interacting rotational landslides (Fig. 9). The cutting zone is reshaped by a series of complex rotational and translational slides. The bodies of landslide are dotted with numerous indicators of 'fresh' instability (shear and friction cracks, fractures, bulges, drunken forest, seepages and stagnant water). Finally, in the most downstream part, the basal undercutting of the lazoughen stream by the suppression of the abutment and the public landfill have worsened the instability. Downstream area is marked by human activities such as farming, earthworks, and housing (Fig. 10).

Various morphological and vegetation indices (chaotic topography, slope breaks, dead trees) are evidence of the landslide (Fig. 9). According to local witness the landslide occurred for the first time in February 1973 and was successively reactivated on April 1974, on March 1985 and on March 2012 . This is a typical rotational landslide with a moderately sloping curved main scarp, longitudinal cracks and a rotational slide surface. The landslide material is principally made of lower Cretaceous clays. The locations of the photos taken (1-6) of figure 9 are shown on Fig. 10.

\section{The landslide-inducing factors}

The occurrence of the large Ighil Bouzel landslide can be attributed to two causative factors: (i) The triggering factors related to the antecedent rainfall and human activity through slope excavations embankment and deforestation; (ii) The susceptibility factors such as geology, morphology, hydrogeology and geotechnical characteristics of the soil.

\subsection{Influence of rainfall on landslides: antecedent rainfall}

Rainfall is largely regarded as the principal triggered factor of landslides. Prolonged and low intensity of rainfall often generates deep-seated landslide movements versus shallow soil landslides are mostly triggered by brief and intense rainfall (Hong et al. 2005). The historical landslides inventory carried out over the period of 1950-2014 shows that the main landslides in the city of Azazga are related to heavy rainfall event that exceeded $900 \mathrm{~mm}: 1952$ (1190,8 mm), 1955 (992 mm), 1973 (1287,8 mm), 1974 (884 mm), 1984 (1236,1 mm), 1985 (930,7 mm), 2003 (999,6 mm), 2004 (917,6 mm) and 2012 (2086,7 mm). Landslides mainly triggered during the rainy period (October at April) during an average an average precipitations exceeding $500 \mathrm{~mm}$. Such a high intensity and accumulation of rainfall can be enough to trigger certain types of landslides whereas for others type of landslides an exceptional climatic events is needed. However, the antecedent rainfall has influence the degree of saturation of the soil and consequently, plays an important role for the initiation of the landslides (Godt et al., 2006). The peaks of cumulated precipitations over these months reached $876 \mathrm{~mm}$ in 1952 (73\% of the annual amount), $557 \mathrm{~mm}$ in 1955 (56\% of the annual amount), $841 \mathrm{~mm}$ in 1973 (65\% of the annual amount), $477 \mathrm{~mm}$ in 1974 (73\% of the annual amount), $852 \mathrm{~mm}$ in 1984 (68\% of the annual amount), $575 \mathrm{~mm}$ in 1985 (62\% of the annual amount), $544 \mathrm{~mm}$ in 2003 (54\% of the annual amount), $886 \mathrm{~mm}$ in 2004 (97\% of the annual amount) and $691 \mathrm{~mm}$ in 2012 (33\% of the annual amount). During the winter season of 2012 (December to February), the Azazga region experienced prolonged and intense rainfall with the cumulative rainfall exceeding $550 \mathrm{~mm}$ that represents $55 \%$ of the total annual rainfall (Fig. 5). From January to March repeated rainfall episodes with high intensity resulted in a cumulative peak rainfall reached $700 \mathrm{~mm}$ which represents $65 \%$ of the annual precipitations (Fig. 5). The first rainfall episode, from $12^{\text {th }}$ to $17^{\text {th }}$ January, was characterized by cumulative precipitation in excess of $80 \mathrm{~mm}$. The second rainfall episode, from $19^{\text {th }}$ to $28^{\text {th }}$ January, was severe, and was as much as $153 \mathrm{~mm}$. The third rainfall episode, from $2^{\text {th }}$ to $13^{\text {th }}$ February, was characterized by more severe precipitation in the range from $161 \mathrm{~mm}$. The fourth episode, from $18^{\text {th }}$ to $28^{\text {th }}$ February, was characterized by cumulative precipitation around $71 \mathrm{~mm}$. The last rainfall episode, from $1^{\text {th }}$ to $14^{\text {th }}$ March, was characterized by cumulative value exceeding $85 \mathrm{~mm}$ and the maximum daily rainfall exceeding $20 \mathrm{~mm}$. The antecedent rainfall at that time could be the principal cause that induced the failure of the Ighil Bouzel slope. During the continuous and frequent heavy rainfall the infiltrated water increase the groundwater level and pore pressure in both the upper-soil slope and the lower-rock slope that contribute to the alteration of the material in interlayers and the degradation of its mechanical resistance with the loss in the shear strength, which finally influenced the slope stability. Continual rainfall may have increased the water content of the sliding mass and saturated the slip zone, leading to a major loss in the shear strength of the sliding zone. Therefore, the stability of the slope progress to the state of limit equilibrium. Still, though long-term rain infiltration exists, the groundwater level still increases considerably because of the low permeability of the slope.

\subsection{The human activity}

The human activity represented by intense and fast-unplanned urbanization mainly since 1978, has led to significant morphological changes in the stability conditions by deforestation, excavation, embankments, land use changes, slope cutting for constructions and road increasing, hence, the frequency of Ighil Bouzel landslide. The most affected zones by landslides correspond to the badly protected one where the natural vegetation is degraded by deforestation, excavations and urbanization. These excavations degraded the quality of the soil mass, decreased the holding force of the slope and moved the lower rock slope towards a disequilibrium unstable state, which finally contributed to the slope failure. The gradual extension of the urban area with extensive land use activities in the northern parts of the city along inappropriate land use, environmental mismanagement and a lack of rules and regulations constitute the main factors of the increase of the frequency of landslides. Deforestation, with the removal of trees and the clearing of land for crops, increases the infiltration of rainwater into the soil, which has a negative impact of the slopes stability.

\subsection{Local geomorphology}


The Ighil Bouzel landslide is located on a wide north-facing slope of $250 \mathrm{~m}$ to $500 \mathrm{~m}$ of altitude. It occurred on a steep slope with the slope dipping $10-20^{\circ}$ northward (Fig. 11). The slope of the lower rock, with a structure of flysch bedding planes, was relatively steeper than the upper earth slope consisting of a thick layer of scree. In addition, the dip of the diaclase and the flyschs schistosity planes are dipping in the slope direction. Moreover, the morphology shows watershed with the presence of concave slope depression that favor natural accumulation of surface and subsurface runoff and likely groundwater during the storms, thereby making them more susceptible to landslides. The slope is cut by a set of valleys that forms the main artery of the lazoughen stream. The valleys have narrow bottoms and steep slopes with dominant south-east - north-west direction. The lazoughen network converges towards the main landslide area located between the settlements of Tala Oukouchah and Ighil Bouzel (Fig. 11). Field observations showed a relatively steep slope about $15^{\circ}$ where the landscape show a mottled morphology and greater deformation with counter slopes, small displacement sheets, old tearing scars and small to high escarpments that characterize low unstable slopes (Figs. 7, 9 and 11). The landslide zone is characterized by a series of bulges parallel to the general slope and separated by the main scarps (Figs. 11). A series of tension cracks of varying depths and lengths were also encountered in the downstream part of the unstable slope (Fig. 11). Semi-permanent torrential-type flows have created gullies in the slope and caused shifts in the banks. Slope movements affects thick scree slopes that are widely developed on the surface and clearly visible in the landscape by their hilly shape and low vegetation cover. Human activities, especially after 1980 with large private constructions has led to a notable morphological modification by earthworks, filling and opening of access roads to the different districts. Through these geomorphic features, the entire slope presented limited equilibrium under normal conditions.

\subsection{Local geologyand structure}

According to the field surveys, borehole data, the landslide structure is mainly represented by overlying thick Quaternary-scree deposits as upper-earth slope and the underlying bedrock of the Cretaceous flyschs as lower rock slope (Figs. 3 and 6). The analysis of lithological section across the landslide zone established from the boreholes and surface observations extending from the city to the lazoughen river allows us to identify two lithological units (Fig. 11b): (i) The Cretaceous flyschs which forms thick series of gray to greenish clays finely bedded, folded and friable, can be cut into thin platelets, moist on the surface and compact at depth forming the substratum of the site. The borehole sections indicate thick-bedded and highly fractured hard rock belonging to the Cretaceous allochthone complex (Gelard, 1979). The flyschs deposit is intersected by most of the boreholes at depth ranging between 3 and $31 \mathrm{~m}$ as shown on the cross section AA' (Fig.12b). The depth decrease from the north to south from $5 \mathrm{~m}$ to $31 \mathrm{~m}$ and from the west to the east from $10 \mathrm{~m}$ to $25 \mathrm{~m}$, (ii) The quaternary screes that cover the Cretaceous flyschs is made of sandstone blocks of different sizes embedded in a clayey to sandy-clay deposits.

The tectonic discontinuities (faults, fissures, shistosity) constitute the drain for water infiltration (Figs. 3 and 6). In addition, the lithological discontinuity between the permeable formations (scree) and the impermeable formations (flysch) constitute a major hydrological discontinuity planes.

\subsection{Local hydrology and hydrogeology}

The study area is crossed by a drainage network essentially represented by the lazoughen and Aboud permanent flow waterways associated with their temporary flow affluent drainage network. These watercourses with an irregular flow regime, sometimes becoming excessive during the wet season. The 'fluvial and torrential' system of lazoughen and Aboud rivers passed through the slope toe generates a significant runoff, saturation of the soil, basal erosion on the banks, strong under cutting erosion of the slope accompanied by lateral undermining of the banks, which activates the dynamics of the slope and caused the removal of the slope toe (removal of abutment). Runoff water infiltration into the soil is possible through the presence of tectonic discontinuities and the existence of local, more permeable sandy layers (scree). Seasonal exceptional precipitation sequences combined with the processes of erosion, and infiltration increase the water content and the saturation of the soil layers that decreases the effective stress in the soil, and reduces shear strength, resulting in slope movement. The river dynamics that influence the triggering of landslides are generated by the concentrated runoff of water and are conditioned by the flow rates as well as by the lithology and slope. This process is observed in the lazoughen and Boulina streams in 2012 and is manifested by basal erosion by the river torrents that lead to collapse at the foot of the slope. Seasonal heavy rainfall and fluvial incision by the river may induce failure of the banks due to slope undercutting and seriously influenced the slope stability. Moreover the Quaternary scree deposits that overlapping the clay flyschs is relatively permeable and can allow water flow channels and form groundwater table on the relative impermeable clay bedding surface where water accumulate within the vertical tension cracks during wet seasons. The infiltration of water into the contact zone between the scree deposits and the underlying flysch marls can decompression of the marls and causing the collapse of scree along the versants.

The analysis of the static level map of groundwater table based on the inventory of 78 water points ( 13 piezometers, 4 sources and 60 wells) by using Kriging interpolation (Isaaks and Srivastava, 1989) shows the presence of a continuous and generalized shallow groundwater with a static level of the groundwater table at depth ranging between 2.5 to $5 \mathrm{~m}$ (Fig. 12a). This groundwater is contained in the quaternary sandy-silty cover formations (scree) which are quite permeable. The values of static level of the groundwater table increase from the South to North indicating a water flow from south toward the North. Figure $12 \mathrm{~b}$ illustrates the lithological structure of the landslide and the groundwater table in the landslide zone. Considering the lithological and the hydrogeological conditions of this landslide, the groundwater is mainly found in the cover quaternary scree, which could be contained in the contact area between the bedrock (flych) and the overlying deposits (scree). Groundwater is discharged to the ground surface in the form of a sources, springs and water wells (Figs. 4 and 13). The groundwater level is seasonally influenced by rainfall and closely associated with the amount of precipitation and may be quite high when the monthly precipitation is high as observed during heavy rainfall through sources and wells (Figs. $13 \mathrm{c}$ and d). The basement probably remains saturated all year. The hydrogeological conditions of the subsoil, which is often saturated, explain the low stability of the soil when the natural slopes exceed $10^{\circ}$. Indeed, the shallow water table in the study area increases the susceptibility of the deposits to landslide during rainfall events. The river dynamics that influence the triggering of landslides are generated by the concentrated runoff of water and are conditioned by the flow rates as well as by the lithology and slope. This process is observed in the lazoughen stream and is manifested by water undercutting that lead to collapse at the foot of the slope (Fig. 13a and b). Seasonal heavy rainfall and fluvial incision by the river seriously influenced the slope stability and seriously damaged soil structures.

\subsection{Geotechnical characteristics}


Lithologicaly, the landslide area is characterized by the impermeable flyschs bedrock basement overlain by permeable Quaternary scree deposits. Comprised of a loose and porous soil layer which makes it favorable for surface water infiltration and groundwater retention. The flyschs that is not outcropping in the landslide area is mostly constituted by blue clays at the base and green at the top. The basement depth ranges between 3 to $31 \mathrm{~m}$ as shown on the cross section AA' (Fig. 12b). The quaternary screes deposits cover, almost the whole studied area (see the cross sections AA') and are represented by sandstone blocks embedded in a clay-sandy deposits.

The statistical analysis of the geotechnical data allowed us to distinguish three geotechnical units (Table 2): (1) Blue and green clays form the flysch substratum with variable geotechnical characteristics that include two terms (Table 2): (i) The Weathered greenish-grey clays correspond to the upper part of the weathered flysch bedrock. They coincide with a fine soil $(56<\mathrm{Fc}<98 \%)$ that is moderately dense $\left(1,35<\mathrm{y}_{\mathrm{d}}<1,88 \mathrm{t} / \mathrm{m}^{3}\right)$, saturated $(\mathrm{Sr}$ of $93 \%)$, plastic and very sensitive to the presence of water (LL vary between 48 and 77\% and PL between 20 and 37\%). They have low cohesions (Ccu between 0,15 bars and 1,3 bars) and low angles of friction $\left(1,91^{\circ}<\Phi \mathrm{Cu}<22^{\circ}\right)$. The oedometric tests showed a fairly to moderately compressible soil (Cc between $11 \%$ and $24 \%$ ) and swellable soil (Cg between 2,8\% and 9\%), (ii) The Compact grey-blue clays corresponds to the compact part of the Cretaceous flysch substratum at depth. The statistical analysis of the physical parameters, showed a fine soil $(55<\mathrm{Fc}<100 \%)$, of average density that increases strongly with the depth $\left(\mathrm{Y}_{\mathrm{d}}\right.$ ranges between 1.52 and 2 $\left.\mathrm{t} / \mathrm{m}^{3}\right)$. The degree of saturation reaches $100 \%$ in the first few meters and then $\left.\mathrm{Sr}=37 \%\right)$ at depth. The soil is classified as not very plastic $(\mathrm{LL}=50 \%$ and $\mathrm{PL}=$ 22). Shear tests showed deep and undisturbed clays (Ccu between 0,06 and 1,6 bars and $\varphi$ between 0,6 and $33^{\circ}$ ). The oedometric tests classify the soil as moderately compressible (Cc around 20\%), and swellable (Cg around 8\%). (ii) The Sandy-clay scree corresponds to multi-sized sandstone blocks, embedded in a sandy-clay deposits. The granulometric analysis, shows sands and clays presenting $15 \%$ to $97 \%$, respectively, of grain size. The physical characteristics showed a non- saturated to saturated soil $(10<\mathrm{Sr}<90 \%)$, of low to high density $\left(1.4<\gamma_{d}<1.93 \mathrm{t} / \mathrm{m}^{3}\right)$ and low to medium plasticity (LL= 23 to $35 \%$ and $\mathrm{PL}=7$ to $35 \%$ ). Resistance tests of non-drained shear showed low to medium cohesions (Cuu between 0,03 bars to 0,95 bars) and low to medium angles of friction $\varphi^{\circ}$ (UU) between $1,8^{\circ}$ and $18^{\circ}$. The results of the oedometer tests reveal sandy clays that are moderately compressible (average Cc between 6 and $34 \%$ ) and not very swellable ( $\mathrm{Cg}$ of 2 and $11 \%$ ). Geotechnical tests results showed that the upper part of the flysch bedrock is plastic, weathered and very sensitive to water with a low mechanical strength very favorable to landslides. The significant variation in the physical and mechanical characteristics of the soils is confirmed by our field observations which showed saturated, reworked and altered clays at the surface, subjected to shrinkage and swelling traversed by a network of cracks, widely open due to the development of high pore pressures thus favoring occurrence of landslides. In addition, the flysch bedding structure of the overlying soft rock (altered) and underlying hard rock (bedrock) was extremely sensitive to water infiltration and easy formation of a shear slipping surface along this weak interlayers and consequently ultimately susceptible to landslide. The sliding zone is a continuous thick shear zone located in weathered upper part of the flysch.

\section{Mechanism analysis}

The Ighil Bouzel gravitational slope correspond to a complex deformation mechanisms resulting from a superimposition of a multitude of slide surfaces. The failure mechanisms of this rainfall-induced complex landslide were the result of the combination of antecedent rainfall, geological structures, geomorphologic settings and human activities. Rainfall was the principal triggering factor that reduced the mechanical strength of the soil and lead to a disequilibrium/unstable state, leading to different failure mechanisms and mass movements.

The infiltration of the antecedent rainfall through the permeable scree deposits made of sandy clay and sandstone blocks overlying the impermeable flysch bedrock allowed the retention of groundwater. In the meantime, the water content and pore water pressure reduced the mechanical strength the soil mass and resulted in the progressive slope deformation with appearance of the sliding surface. In addition, the lithological interface scree / flyschs constitute the shear zone that controlled and favored the slope movements. The bedding planes, the dip of the schistosity and the diaclase planes of the flyschs in the slope direction. More exactly, a shear-sliding surface can easily form along the bedding planes, which could finally be responsible for the formation of the slide. As well, rainwater infiltration resulted in a reduction in the shear strength of the impermeable interface stratum of the muddy schist that is often altered with low geotechnical characteristics due to long-term immersion. This interface (geotechnical interface) layer that formed a shear slip plane correspond to the upper part of the weathered greenish-grey clays of the flysch. In addition, the basal erosion of the lazoughen and Aboud rivers torrent at the toe of the rock slope decreasing the retaining force and driving the slope towards a destabilization.

To characterize the dynamic nature of the unstable slope and particularly the Identification of the shape and depth of the failure surfaces was possible based on information gathered from field observation, analysis of the inclinometric measurements results and geophysical Electrical resistivity tomography (ERT) investigations. The field observations showed several indications of instability such as an irregular morphology resulting from the existence of several different ground failure lines, several deep and shallow landslides surfaces were recognized on the slope. At depth, the rupture zone was defined based on inclinometric monitoring and geophysical (ERT) investigation carried out along and across the largest landslide areas (Figs. 14 and 15). The location of inclinometers and ERT profiles is shown on Figure 4.

\subsection{Inclinometric data interpretations}

Six inclinometer tubes identified as BI1, BI2, BI3, BI4, BI5 and BI6 were installed at the Ighil- Bouzel site at depth varying from 24 to $36 \mathrm{~m}$ (Fig. 14 ). The measurements were performed by the LCTP in 2014. The objective of the inclinometric measurements is to determine the depth of the failures and the amplitude as well as the direction of the horizontal displacement of the ground as a function of time. The measurement procedure is based on the French standard NF 94 156. The resulted inclinometric measurements are presented in the form of curves indicating for each inclinometer the angular variations and displacements in the A direction and in direction B perpendicular to A. The resulting inclinometers are also correlated with the boreholes. Several curves are superimposed on each graph, showing the evolution of the angular variations or the displacement as a function of time. The curves show different deformations and their evolutions overs time. These curves clearly show the depth of the rupture surfaces (Fig. 14). Table 3 summarizes the results of these measurements. The obtained results show that (Fig. 14): (i) All the inclinometers showed a failure surface; (ii) The BI1, BI2, BI 4 and BI5 inclinometers show

Page $10 / 29$ 
similar evolution speeds, higher than those observed in SI3 inclinometer; (iii) The deformation is millimeter sized in the same directions A for all inclinometers. The average displacement the lowest and the displacement concerns a subset of the large landslide which seems started from Tadart district and to develop in the north-west direction, towards the lazoughen river; (iv) The failure surface varies from minimum $11 \mathrm{~m}$ to maximum depth of $28 \mathrm{~m}$. The failure surface located at the interface between the scree and the flyschs layer. Precisely, it is located in the upper part of the weathered, plastic clays flysch bedrock and ( $\mathrm{v}$ ) All the inclinometers showed a fracture surface that coincides with the roof of the flysch bedrock identified by the boreholes except for the inclinometer BI3 which identifies a surface at $28 \mathrm{~m}$ located inside the scree deposit. (vi) The mean displacement for the period 2012-2013 is approximately $0.01 \mathrm{~mm}$ to 0.076 $\mathrm{mm} \mathrm{day}^{-1}$ i.e. a magnitude of 1 to $28 \mathrm{~cm}_{\text {year }}{ }^{-1}$ for the average displacement (Tab. 3). The movement moving in the Northwest direction toward the lazoughen and Aboud rivers (Fig. 10). According to the classification of Lateltin, 1997, the actual mean velocity makes the Ighil Bouzel an active to very active landslide with a fast phases.

In summary, the results of inclinometric measurements show a complex, deep-seated (11 - $28 \mathrm{~m}$ deep) and active moving landslide with an average velocity of 0,01 to $0,28 \mathrm{~m} \mathrm{yr}^{-1}$. The measured fracture depths are localized, preferably at the base of the quaternary scree layer (Fig. 14). In addition, the fractures are located below the water table level. The possibility of several superimposed failure surfaces cannot be excluded according to the hydrogeological structure (Fig. 12b). Based on the inclinometer results correlated with the boreholes, the entire slip surface is located along the interface between the flyschs bedrock and the overlying scree. The sliding zone correspond to the weathered upper part of flysch bedrock (shear zone) with thickness 0,5 to $5 \mathrm{~m}$. The shear resistance characteristics of the soil in the sliding zone (geotechnical interface), shows a saturated, plastic oil with low cohesions and low angles of friction.

Based on the speed activity, the Ighil Bouzel landslide can be classified into two active zones: (i) the rear low activity zone in upstream with an average velocity of 0,1 to $3,6 \mathrm{~cm} / \mathrm{yr}$. This area is characterized by a slight deformation features. It has an average depth of $14.5 \mathrm{~m}$, an area of $400 \times 470 \mathrm{~m}^{2}$, and an estimated volume of $27.26 \times 10^{5} \mathrm{~m}^{3}$ and (ii) the front high activity zone in downstream (Figs. 7, 8, 9, 10, 11 and 12) with extended and dense deformations. The extent is approximately $1170 \times 550 \mathrm{~m}^{2}$ in area, the mean thickness is $18 \mathrm{~m}$, and the volume estimated is around $115.83 \times 10^{5} \mathrm{~m}^{3}$. These inclinometer results are in concordance with the results of observed morphology and deformation.

\subsection{The electrical resistivity tomography (ERT) data interpretations}

The Electrical Resistivity Tomography (ERT) is the most applied geophysical methods widely used for the sub-surface investigation of landslide because of its relative simplicity and time effectivity. ERT is considered as the most adequate and efficient method for the identification of depth and internal structure of slope deformations. More precisely, it is used for the study the internal characteristics of landslides (such as main body, physical properties, water content, geometry and position of shear surface) based on the spatial distribution of electrical resistivity contrasts of the soil provide by 2D or 3D images (Hack, 2000; Havenith et al., 2000; Mahmut et al., 2006; Perrone et al., 2014; Omowumi Falae et al., 2019).

In this study, the ERT survey was conducted on the first week of January 2020 in a landslide area by CGS in order to verify the distribution of electrical resistivity in the sectors where mass movement was identified and particularly to characterize the internal structures of landslides. Therefore, a 2-D resistivity survey was carried out along four (4) profiles over the landslide by a dipole array device using a 48 electrodes cable $2.5 \mathrm{~m}$ apart with rolling. Profile 1 and 4 was along the axis of landslide while Profile 2 and 3 were across the landslide body (Fig. 15). The data were processed by a resistivity inversion technique using RES2DINV software to achieve electrical imaging along these lines. The ERT test was useful for defining some physical properties and the geometry of the landslide mass.

The results presented in Figure 15 shows the lateral and depth variation of the Resistivity. The simplified logs of the boreholes and inclinometers are also correlated with the obtained tomograms. The resistivity profiles enabled us with boreholes, inclinometers and geotechnical tests to differentiate the mass movements underlying the bedrock. It is clear that the electrical tomography should be combined and calibrated with the available geotechnical data in the studied site. A good concordance between resistivity and inclinometric results was also noted.

The profile 1 was in the direction of NW-SE over a length of about $355 \mathrm{~m}$ (Fig. 15). The Profile cross the borehole BI 2 equipped with an inclinometer at a depth of $35 \mathrm{~m}$ that shows a failure surface at a depth of $24 \mathrm{~m}$. The resulting tomogram along this profile indicates low to high resistivity values. They are in the range of 5-300 $\Omega \mathrm{m}$, and there are two distinct resistivity zones along the line. The zone of low resistivity (10-20 $\Omega \mathrm{m})$, located in all the section, at a depth from 20 to $50 \mathrm{~m}$, probably represents the landslide materials with higher water content. The zone of the high resistivity correspond to the sandstone screes. The landslide material, clay, sand and sandstone blocks units observed in the borehole are in good agreement with the results of the electrical resistivity tomography. The resistivity values strongly decrease with depth in the clay of flysch unit. Then, a conductive zone, which has a resistivity ranging from 5 to 10 $\Omega \mathrm{m}$, is observed, and its thickness varies between 5 and $10 \mathrm{~m}$. This conductive layer might be composed of unconsolidated and water-saturated landslide material that contains clay, mud, sand and silt. The presence of water indicated by low resistivity, values is the key parameter in sliding.

The profile 2, which is almost perpendicular to the direction of the landslide movement, runs from NE to SW (Fig. 15). The profile of about $475 \mathrm{~m}$ length passes through the borehole BI 4 equipped with an inclinometer at a depth of $35 \mathrm{~m}$. The resistivity distribution are low $(10-20 \Omega \mathrm{m})$ in the northeastern part and in the middle of the profile (between 0 and $10 \mathrm{~m}$ ), while they are rather high $(20$ and $300 \Omega \mathrm{m}$ ) in the southwestern part of the profile (between 0 and $40 \mathrm{~m}$ ). At the depth, the resistivity values are very low $(<10 \Omega \mathrm{m})$ in the northeastern and the middle parts of the profile (between 35 and $60 \mathrm{~m}$ ). The low resistivity might be caused by the water content of the unconsolidated material (scree sandstone) while the higher values might be an indicator of the consolidated materials (sandstone blocks). The electrical tomography image is in good agreement with the results of borehole. The schist unit is characterized by very low resistivity values on the tomogram, while the clay, mud, sand and sandstone of scree unit have moderate to high resistivity values. The results show the resistivity contrast that corresponds to the geological interface between the quaternary scree deposits and the Cretaceous flysch substratum. Thus, the presence of an interface, identified by the borehole data, is clearly verified by the resistivity results. 
The third profile crosses the direction of the landslide movement over about $355 \mathrm{~m}$ lenght (Fig. 15). The profile 3 in the direction of NE-SW is passing through the borehole BI 1 equipped with an inclinometer at a depth of $32 \mathrm{~m}$. The obtained ERT result revealed the rupture surface and the subsurface geometry of the landslide. It is considered that the relatively high resistivity layer $(15-250 \Omega \mathrm{m})$ observed in shallow depths might be originated by the landslide material. The thickness of this layer varies between 5 and $15 \mathrm{~m}$ on the tomogram. Also, one can observe that this zone is related with the topographical changes and the depth of groundwater level. Furthermore, the electrical tomography image is in good agreement with the results of borehole: the resistivity tomography image shows that the depth of the landslide that confirmed by the borehole data.

The profile 4 was in the continuity of the profile 1 in the direction of the landslide over a length of about $235 \mathrm{~m}$ (Fig. 15). The profile passes through the borehole BI 2 equipped with an inclinometer at a depth of $35 \mathrm{~m}$. The ERT result obtained along this profile provides very informative result for the determination of the geometry of the landslide and particularly the failure surface. It is considered that the scree layer (clay, sand and sandstone) with relatively high resistivity (15-250 $\Omega \mathrm{m}$ ) blocks observed at the depths ranging between 20-40 m that might be originated by the landslide material composed of unconsolidated and water-saturated landslide material. The zone of relatively very low resistivity (05-10 $\Omega \mathrm{m})$ between the depths of $20-40 \mathrm{~m}$ correspond to clays of flysch unit formed by the consolidated deposits. Thus, the roof of this layer may correspond to the failure surface of the recent landslide. The resistivity results were confirmed by the borehole data of SI 2 that show a surface of rupture at the depths of $24 \mathrm{~m}$.

The ERT method applied in our case landslide area study has allowed to characterize the geometry (shape of the slope, body, surface of rupture) of landslides. The electrical resistivity values along the carried out profiles reveal a structure composed of a layer of displaced scree materials that contains clay, sand and sandstone blocks with relatively high resistivity superimposed on the clayey substratum, which has low resistivity. The resistivity results were confirmed by the boreholes equipped with an inclinometers data.

According to the deformation process and mechanism modes, the Ighil Bouzal landslide presented a complex and progressive failure along the geotechnical interface located in the upper part flysch bedding rock slope. The landslide is favored and controlled essentially by: (1) the lithological discontinuity or interface in the contact zone scree / flyschs; (2) the dip of the flyschs conforming to the slope; (3) the dip of the schistosity and the diaclase planes of the flyschs in the slope direction (4) by the destabilization of the slope by the basal erosion and undercutting of the lazoughen and Aboud rivers torrent. In addition tectonic contacts constitute major hydrological discontinuity planes between permeable formations (scree) and impermeable formations (flysch).

According to the landslide characteristics, a wide range of mitigation measures has been recommended in order to reducing the risk from existing landslides: (i) lowering the aquifers levels with two drainage techniques: deep drainage trenches or galleries combined with radiating drainage boreholes; (ii) restricting and regulations of land-use in landslide prone areas, a function assisted by mapping landslide susceptibility, take the potential geohazards into consideration in urban planning; (iii) requiring by means of codes that human activities (i.e. excavation, construction, grading, cutting slopes, landscaping, irrigation activities, vegetation clearance ...) not contribute to slope instability; (iv) protecting existing developments and population by physical mitigation measures (such as slope geometry modifications, drainage, down counterfort berms that serve as buttresses, and protective barriers, landslide cracks should be covered with plastic sheets) and (v) implementing monitoring and warning systems of the landslide in long-term.

\section{Discussion And Conclusion}

We presented in this study the deformation characteristics, the influencing factors and the failure mechanisms of a large landslide induced by rainfall event on March $12^{\text {th }}, 2012$, that hit the Ighil Bouzel village, in the northern of Azazga city (Algeria). Extensive field investigation, aerial photographs/satellite images interpretation, rainfall data, deep boreholes equipped with piezometers and inclinometers, laboratory tests as well as subsurface geophysical imaging using Electric Tomography (ERT) analysis allowed us to perform an inventory mapping, to analyse the deformation characteristics, the main controlling factors and the failure mechanisms of the landslide.

The inventory map of landslides obtained by analysis and interpretation of high resolution satellite images and aerial photographs completed by field investigation allowed us to identify a large rotational landslide covering an area of $570400 \mathrm{~m}^{2}$ which represents $6.26 \%$ of the total urban area. It appears that the March $12^{\text {th }}$, landslide, which affected a total surface of $0,40 \mathrm{~km}^{2}$, is a partial reactivations of pre-existing landslides.

According to our field investigations, the landslide has experienced a long deformation and a progressive failure and produced various and extensive deformation processes, including a large number of ground fissures, a surface bulges, scarps, minor scarps and tension cracks in the soil. These deformations have caused heavy damage to roads and settlements of houses and public infrastructures (three roads including the national roads RN 12 and RN 71 and eleven houses were damaged), threatening several inhabitants.

The initiation of this rainfall-induced landslide resulted from a combination of two types of factors: (i) triggering factors related to the antecedent rainfall and human activity through slope excavations, embankment and deforestation (ii) susceptibility factors related to the internal geological structures (such as the flysch bedding slope structure) their weak mechanical resistance characteristics, the presence of shallow aquifers, steep slope, basal erosion by the river torrents and human activity through deforestation, slope excavations and embankment.

Rainfalls are certainly the main triggering factor of landslides, such a high intensity and the antecedent rainfall plays an important role for the initiation of the landslides, a series of pluviometric events has been recorded during the event, although their entity was not significant. The earlier reported analyses have showed a critical role of cumulative rainfalls episodes with high intensity over an interval of days. A cumulative peak rainfall reached $19.6 \mathrm{~mm}$ in 24 -hour, exceeding $85 \mathrm{~mm}$ from $1^{\text {st }}$ to $12^{\text {th }}$ March and exceeding $550 \mathrm{~mm}$ during the period of January to March 2012 that represent $65 \%$ of the total annual precipitations. Continual rainfall may have increased the water content of the sliding mass and saturated the slip zone, leading to a major loss in the shear strength of the sliding zone.

Page $12 / 29$ 
In addition the predisposing factors (such as geology, hydrology, hydrogeology), It is important to underline that the frequency and the damage of the landslide are exacerbated by the unplanned urbanization in the unstable zone with public infrastructures, residential buildings and national roads constructed inside and in the proximity of the landslide bodies. However, the choice of location of structures and infrastructure is a key factor in their exposure to hazard. For this, given the presence of the above-mentioned predisposing factors, urban planning is a fundamental option both to avoid an increase in the vulnerability of the area and to limit the economic losses in the case of rainfall events.

Analysis of the inclinometers and Electrical Resistivity Tomography (ERT) results have allowed to characterize the deformation process, the geometry of the landslides and the displacement direction. The results revealed a deep-seated and a rapid-moving landslide with a failure surfaces at depth ranging between $11 \mathrm{~m}$ and $28 \mathrm{~m}$ and an average velocity from 1 to $29 \mathrm{~cm}$.yr-1 with the displacement in the Northwest direction toward the lazoughen and Aboud rivers.

Moreover, the study showed that the landslide presented a complex failure mode in that the upper part of the earth slope initially deformed and slid along geotechnical interfaces between the flysch bedrock and the quaternary scree.

The Ighil Bouzel landslide is a typical active-moving landslide in the hills area with about $1550 \mathrm{~m}$ in length and $550 \mathrm{~m}$ in width. Its mean depth $18 \mathrm{~m}$ and the estimated surface area of the landslide body is $852.5 \times 10^{4} \mathrm{~m}^{2}$ with a volume of $153.45 \times 10^{5} \mathrm{~m}^{3}$. This landslide is considered as partial reactivations of large pre-existing landslide $\left(0,606 \mathrm{~km}^{2}\right)$ which represents $6,65 \%$ of the total urban area. The boundaries of this ancient landslide extend over approximately $1570 \mathrm{~m}$ length, and a width varying from 350 to $550 \mathrm{~m}$. His mean depth $18 \mathrm{~m}$, and the estimated surface area is $852.5 \times 10^{4} \mathrm{~m}^{2}$ with the volume is about $153.45 \times 10^{5}$ $\mathrm{m}^{3}$.

According to the mechanism modes, the slope movements are located in the saturated and weathered zone at the geotechnical interface between the flysch bedrock and the scree cover, favored and controlled essentially by: (i) the lithological discontinuity in the contact zone scree / flyschs; (ii) the dip of the flyschs in the slope direction; (iii) the dip of the schistosity and the tectonic fractures planes of the flyschs in the slope direction (iv) the destabilization of the slope by the basal undercutting by the lazoughen and Aboud rivers torrents.

In order to reduce landslides risk, according to the landslide characteristics, we suggest the following recommendation measures: (i) lowering of the table water level using drainage techniques such as the drainage by deep trenches or galleries combined with radial draining drillings; (ii) regulations and restricting of land-use in landslide prone areas; (iii) Control by means of codes and rules human activities (such as the excavation, construction, embankment, cutting slopes, landscaping, irrigation activities, vegetation clearance, ...); (iv) Control and limit the development of urbanization in these areas; (v) Prohibit any type of development and planning, all types of new construction in the area, all human activities (excavation, construction, development, etc.) landscaping, dyking or backfilling) in the area; (vi) protecting existing developments by physical mitigation measures (such as slope geometry modifications, drainage, down counterfort berms that serve as buttresses, and protective barriers, landslide cracks should be covered with plastic sheets) and (vii) protect and undertake riversides banks protection against torrent undercutting erosional torrent by physical infrastructures such as the modifications of the geometry of the slopes, the drainage, the drain cleaning and protection barriers.

Finally, this paper presents an exhaustive understanding of the deformation characteristics and failure mechanisms of the rainfall-induced large and complex landslide as a useful information for landslide hazard and risk mitigation.

\section{Declarations}

Acknowledgements: This work is supported by the CGS (Centre national de Recherche Appliquée en Genie Parasismique) of Algiers, Algeria. The authors would like to express their thanks and gratitude to the local companies: ASAL, ANRH and LCTP for providing Alsat 2A satellite imagery, rainfall data and geotechnical studies of soils. This work is dedicated to the memory of Eng. Khoukhi Salim geotechnical engineer at LCTP who carried out and monitored all the boreholes and inclinometric tests in the studied zone recently passed away.

\section{Declaration of interests}

\The authors declare that they have no known competing financial interests or personal relationships that could have appeared to influence the work reported in this paper.

\The authors declare the following financial interests/personal relationships which may be considered as potential competing interests:

\section{References}

Algerian daily newspaper, March 11 th 2009. Temps d'Algérie.

Algerian daily newspaper, November 28th 2018. El Watan.

Algerian daily newspaper, Jannuary, 17th 2019. Liberté.

Agence Nationale des Ressources Hydriques ANRH (2019) Precipitation database covering a time-period of 32 years from the 3 meteorological stations: "Azazga Ecole, Yakourene and Freha"

Bourenane H, Bouhadad Y, Guettouche M.S, Braham M, (2014) GIS-based landslide susceptibility zonation using bivariate statistical and expert approaches in the city of Constantine (Northeast Algeria). Bulletin Engineering Geology and Environment. DOI 10.1007/s10064-014-0616-6.

Page $13 / 29$ 
Bourenane H, Guettouche M.S, Bouhadad Y, Braham M (2016) Landslide hazard mapping in the Constantine city, Northeast Algeria using frequency ratio, weights factor, logistic regression, weights of evidence, and analytical hierarchy process methods. Arabian Journal of Geoscience, DOI 10.1007/s12517-0152222-8.

Bourenane H (2017) Analyse spatiale, évaluation et cartographie des risques naturels : Application à l'aménagement de la ville de Constantine (Nord Est Algérien). Thèse de Doctorat Es Sciences. Université de l'USTHB, Alger, pp. 300.

Bourenane H, Bouhadad Y, Guettouche M.S (2019) Flood hazard mapping in urban area using the hydrogeomorphological approach: case study of the Boumerzoug and Rhumel alluvial plains (Constantine city, NE Algeria). Journal of African Earth Sciences. https://doi.org/10.1016/j.jafrearsci.2019.103602

Bourenane H, Bouhadad Y (2020) Spatial analysis, assessment and mapping of flood hazard in the alluvial plains of Boumerzoug and Rhumel (city of Constantine, north-eastern Algeria): application to development and urban planning projects. Bulletin Engineering Geology and Environment. https://doi.org/10.1007/s10064-020-01980-y.

Chau, K.T, Sze Y.L, Fung M.K.,Wong,W.Y, Fong E, Chan L.C.P (2004) Landslide hazard analysis for Hong Kong using landslide inventory and GIS. Comput. Geosci. 30 (4), 429-443. https://doi.org/10.1016/j.cageo.2003.08.013

CGS (2010) Etude de microzonage sismique de la ville de Azazga (Etape A2: Carte photogéologique). Rapport interne non publié.

CGS (2014) Des campagnes piézométriques réalisées pour l'étude de Microzonage sismique de la ville d'Azazga.

CGS (2018) Seismic microzoning study of the city of Azazga. National Center of Applied Research in Earthquake Engineering CGS (Etape A3: Carte géotechnique et données hydrogéologiques). Unpublished Internal reports.

Dai FC, Lee CF (2001) Frequency-volume relation and prediction of rainfall-induced landslides. Eng Geol 59 (3-4):253-266. https://doi.org/10.1016/S00137952(00)00077-6;

Dai F.C, Lee, C.F (2002) Landslide characteristics and slope instability modeling using GIS, Lantau Island, Hong Kong. Geomorphology 42, $213-228$. https://doi.org/10.1016/S0169-555X(01)00087-3

Djerbal L, Alimrina N, Melbouci B, Bahar R (2012) Mapping and Management of Landslide Risk in the City of Azazga (Algeria) Landslide Science for a Safer Geoenvironment pp 463-468. DOI https://doi.org/10.1007/978-3-319-05050-8_72

Djerbal L, Khoudi I, Alimrina N, Melbouci B, Bahar R (2017) Assessment and mapping of earthquake-induced landslides in Tigzirt City, Algeria. Natural Hazards. July 2017, Volume 87, Issue 3, pp 1859-1879. DOI https://doi.org/10.1007/s11069-017-2831-5

Harp E.L, Keefer D.K, Sato H.P, Yagi H (2011) Landslide inventories: the essential part of seismic landslide hazard analyses. Eng. Geol. 122 (1-2), 9-21. https://doi.org/10.1016/j.enggeo.2010.06.013

Hack R (2000) Geophysics for slope stability. Surv Geophys 21:423-448.

Havenith H.B, Jongmans D, Abdrakhmatov K, Trefois P, Delvaux D, Torgoev I.A (2000) Geophysical investigations of seismically induced surface effects: case study of a landslide in the Suusamyr valley, Kyrgyzstan. Surv Geophys 21:349-369. DOI https://doi.org/10.1023/A:1006788808145

Hong Y, Hiura H, Shino K, Sassa K, Suemine A, Fukuoka H, Wang G (2005) The influence of intense rainfall on the activity of large-scale crystalline schist landslides in Shikoku Island, Japan. Landslides 2(2):97-105. https://doi.org/10.1007/s10346-004-0043-z

Gelard J.P (1979) Géologie du Nord - Est de la Grande Kabylie (un segment des zones interne de l'orogène littoral maghrébin) - Thèse de doctorat.

Godt J.W, Baum R.L Chleborad A.F (2006) Rainfall characteristics for shallow landsliding in Seattle, Washington, USA. Earth Surf Proc Land 31(1):97-110. doi:10.1002/esp.1237.

Guettouche M.S (2012) Modeling and risk assessment of landslides using fuzzy logic. Application on the slopes of the Algerian Tell (Algeria). Arabian Geosci 39:1866-751. doi:10.1007/s12517-012-0607-5.

Guzzetti F, Mondini, A.C, Cardinali M, Fiorucci F, Santangelo M, Chang K (2012) Landslide inventory maps: new tools for an old problem. Earth Sci. Rev. 112 (1-2), 42-66. https://doi.org/10.1016/j.earscirev.2012.02.001

Lateltin $O$ (1997) Prise en compte des dangers dus aux mouvements de terrain dans le cadre des activités de l'aménagement du territoire. Recommandations. Office fédéral de l'aménagement du territoire (OFAT), Office fédéral de l'économie des eaux (OFEE), Office fédéral de l'environnement, des forêts et des paysages (OFEFP), $42 \mathrm{pp}$.

LCTP (1998) Etude géotechnique des sols du Centre culturel Azazga. Unpublished Internal reports. Laboratoire des Travaux Publics.

LCTP (2004) Etude géotechnique du POS A1 et A5. Unpublished Internal reports. Laboratoire des Travaux Publics.

LCTP (2014) Etude géotechnique du POS A1 et A5. Unpublished Internal reports. Laboratoire des Travaux Publics

Page 14/29 
Mahmut G, Drahor Gokhan G.o, kturkler Meric A, Berge T, Ozgur K (2006) Application of electrical resistivity tomography technique for investigation of landslides: a case from Turkey. Environ Geol (2006) 50: 147-155. DOI https://doi.org/10.1007/s00254-006-0194-4

Michiue M (1985) A method for predicting slope failures on cliff and mountain due to heavy rain. Nat Disaster Sci 7(1):1-12. DOI:10.1016/01489062(87)90777-7

ORGM (1996) Geological map of Azefoune at 1/50. 000scal, Publ. Serv. Géol. Algérie.

Omowumi Falae P, Prasanna Kanungo D, Kumar Singh Chauhan P, Kumar Dash R (2019) Electrical resistivity tomography (ERT) based subsurface characterisation of Pakhi Landslide, Garhwal Himalayas, India Environmental Earth Sciences (2019) 78:430. https: //doi .org/10. 1007/s 12665-019-8430-x.

Perrone A, Lapenna V, Piscitelli S (2014) Electrical resistivity tomography technique for landslide investigation: A review. Earth-Science Reviews 135 (2014) 65-82. http://dx.doi.org/10.1016/j.earscirev.2014.04.002.

Riheb H, Abd errahmane B, Yacine L, Mustapha B, Abd El Madjid C, Abdeslem D (2012) Geologic, topographic and climatic controls in landslide hazard assessment using GIS modeling: a case study of Souk Ahras region, NE Algeria. Quat Int 302(2013):224-237. https://doi.org/10.1016/j.quaint.2012.11.027

Varnes DJ (1978) Slope movements: type and processes. In: Eckel EB (ed) Landslides analysis and control. Transp Res Board Spec Rep 176:11-33.

\section{Tables}

Table 1: Maximum rainfall intensities at the rain gauges close to the study area for the $12^{\text {th }}$ March 2012 rainfall event.

\begin{tabular}{|llllll|}
\hline $\begin{array}{l}\text { Rainfall intensities } \\
\text { Rain gauges }\end{array}$ & Daily rainfall $(\mathbf{m m})$ & $\mathbf{3}$ days rainfall $(\mathbf{m m})$ & $\mathbf{7}$ days rainfall $(\mathbf{m m})$ & $\mathbf{1 0}$ days rainfall $(\mathbf{m m})$ & $\mathbf{1 5}$ days rainfall $(\mathbf{m m})$ \\
\hline Azazga Ecole & 19,6 & 25,9 & 85,5 & 114,3 & 174,7 \\
\hline Yakourene & 21,8 & 23 & 32,6 & 92,6 & 149 \\
\hline Freha & 14,5 & 20 & 29,9 & 50,9 & 72 \\
\hline
\end{tabular}

Table 2: Statistical parameters of the soil analysis results of study area.

\begin{tabular}{|c|c|c|c|c|c|c|c|c|c|}
\hline Soil parameters & $\begin{array}{l}\text { Fc } \\
(\%)\end{array}$ & $\begin{array}{l}\mathrm{yd} \\
\left(\mathrm{t} / \mathrm{m}^{3}\right)\end{array}$ & $\begin{array}{l}\mathrm{Sr} \\
(\%)\end{array}$ & $\begin{array}{l}\mathrm{PL} \\
(\%)\end{array}$ & $\begin{array}{l}\mathrm{LL} \\
(\%)\end{array}$ & $\begin{array}{l}\text { Ccu } \\
\text { (bar) }\end{array}$ & $\begin{array}{l}\Phi \mathrm{cu} \\
\left({ }^{\circ}\right)\end{array}$ & $\begin{array}{l}\text { Cc } \\
(\%)\end{array}$ & $\begin{array}{l}\mathrm{Cg} \\
(\%)\end{array}$ \\
\hline Lithology & $\begin{array}{l}\text { Min - } \\
\text { Max } \\
\text { Average }\end{array}$ & $\begin{array}{l}\text { Min - } \\
\text { Max } \\
\text { Average }\end{array}$ & $\begin{array}{l}\text { Min- } \\
\text { Max } \\
\text { Average }\end{array}$ & $\begin{array}{l}\text { Min-Max } \\
\text { Average }\end{array}$ & $\begin{array}{l}\text { Min- } \\
\text { Max } \\
\text { Average }\end{array}$ & $\begin{array}{l}\text { Min- } \\
\text { Max } \\
\text { Average }\end{array}$ & $\begin{array}{l}\text { Min- } \\
\text { Max } \\
\text { Average }\end{array}$ & $\begin{array}{l}\text { Min-Max } \\
\text { Average }\end{array}$ & $\begin{array}{l}\text { Min- } \\
\text { Max } \\
\text { Average }\end{array}$ \\
\hline \multirow[t]{2}{*}{$\begin{array}{l}\text { The Cretaceous weathered greenish-grey } \\
\text { clays }\end{array}$} & $56-$ & $1.35-1.88$ & $\begin{array}{l}81.5- \\
100\end{array}$ & $\begin{array}{l}20.11- \\
37.76\end{array}$ & & & $1.91-$ & $\begin{array}{l}12.36- \\
24.21\end{array}$ & $2.8-$ \\
\hline & $\begin{array}{l}98 \\
82\end{array}$ & 1.61 & 93.37 & 29.05 & $\begin{array}{l}77 \\
62.98\end{array}$ & 0.49 & $\begin{array}{l}22 \\
7.702\end{array}$ & 20.54 & $\begin{array}{l}8.9 \\
6.68\end{array}$ \\
\hline \multirow[t]{3}{*}{ Cretaceous compact grey-blue clays } & 55,000 & 1,520 & 37,170 & 9,800 & 21,220 & 0,060 & 0,600 & 13,810 & 4,090 \\
\hline & 100 & 2,020 & 100 & 33,070 & 69,000 & 1,600 & 33,500 & 37,140 & 11,370 \\
\hline & 84,743 & 1,754 & 89,637 & 22,601 & 50,293 & 0,581 & 9,140 & 20,050 & 7,983 \\
\hline \multirow[t]{3}{*}{ Quaternary screes } & 15,000 & 1,410 & 10,680 & 7,230 & 23,000 & 0,030 & 1,800 & 5,970 & 1,960 \\
\hline & 97,990 & 1,930 & 100 & 35,010 & 35,01 & 0,950 & 18,520 & 34,540 & 11,740 \\
\hline & 66,358 & 18,537 & 85,227 & 20,76 & 20,764 & 0,435 & 7,481 & 20,877 & 6,800 \\
\hline
\end{tabular}

Fc: Fraction of the fines particles, Sr: Degree of saturation, yd: Dry density, LL: Liquidity limit, PI: Plasticity limit, Ccu: cohesions, $\Phi c u$ angles of friction, Cc: coefficient of compressibility and $\mathrm{Cg}$ : coefficient of swelling.

Table 3: The inclinometric measurements results. 


\begin{tabular}{|c|c|c|c|c|c|c|c|c|c|c|}
\hline \multirow[t]{2}{*}{ Inclinometer } & \multirow{2}{*}{$\begin{array}{l}\text { Drilling } \\
\text { depth } \\
\text { (m) }\end{array}$} & \multirow{2}{*}{$\begin{array}{l}\text { Depth } \\
\text { of } \\
\text { rupture } \\
\text { (m) }\end{array}$} & \multicolumn{8}{|c|}{ Speed of displacements for periods of year 2012 and 2013 (cm/days) } \\
\hline & & & $16 / 04 / 2012$ & $19 / 04 / 2012$ & $25 / 04 / 2012$ & $29 / 04 / 2012$ & $07 / 05 / 2012$ & $13 / 05 / 2012$ & $20 / 05 / 2012$ & $29 / 05 / 20$ \\
\hline BI 1 & 32.50 & 11.00 & 0.06 & 0.05 & 0.04 & & & & & \\
\hline BI 2 & 35.00 & 24.00 & & 0.01 & 0.04 & & & & & \\
\hline BI 3 & 34.50 & 28.00 & & & & 0.08 & 0.09 & 0.06 & & \\
\hline BI 4 & 35.00 & 12.00 & & & & & & 0.03 & 0.02 & 0.02 \\
\hline BI 5 & 36.00 & 15.00 & & & & & & & & \\
\hline BI 6 & 35.00 & 14.00 & & & & & & & & \\
\hline
\end{tabular}

\section{Figures}

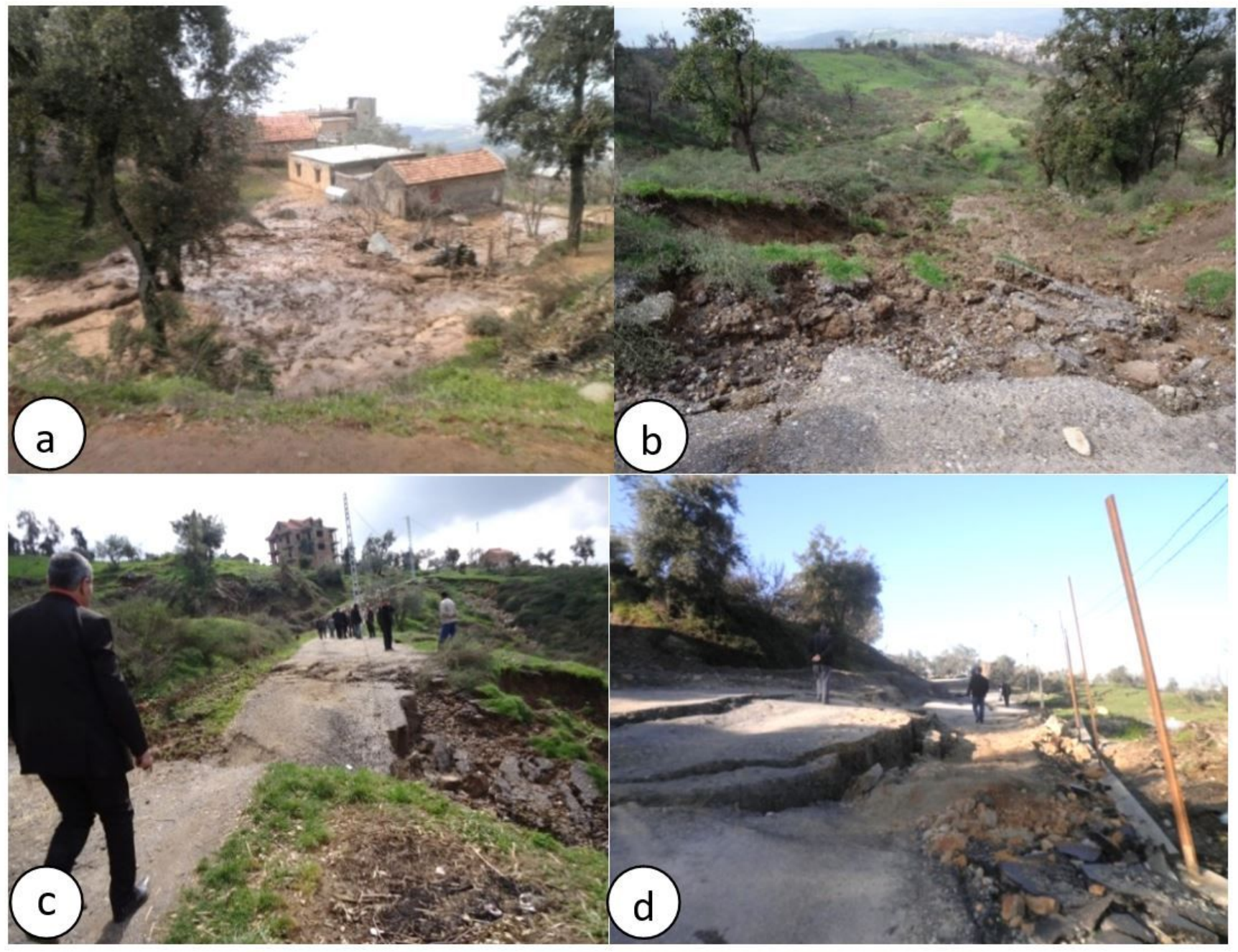

Figure 1

Examples of different types of landslides induced by the March 12th, 2012 rainfall event in the city of Azazga: a) debris flow and damage to constructions in Agouni Guizem in the southeast of the city, b) debris flow along the Boulina River in the south, c) damages of municipality road in the Agouni Guizem, d) damage along national road RN 12 in Ighil Bouzel and Zen in the north. 


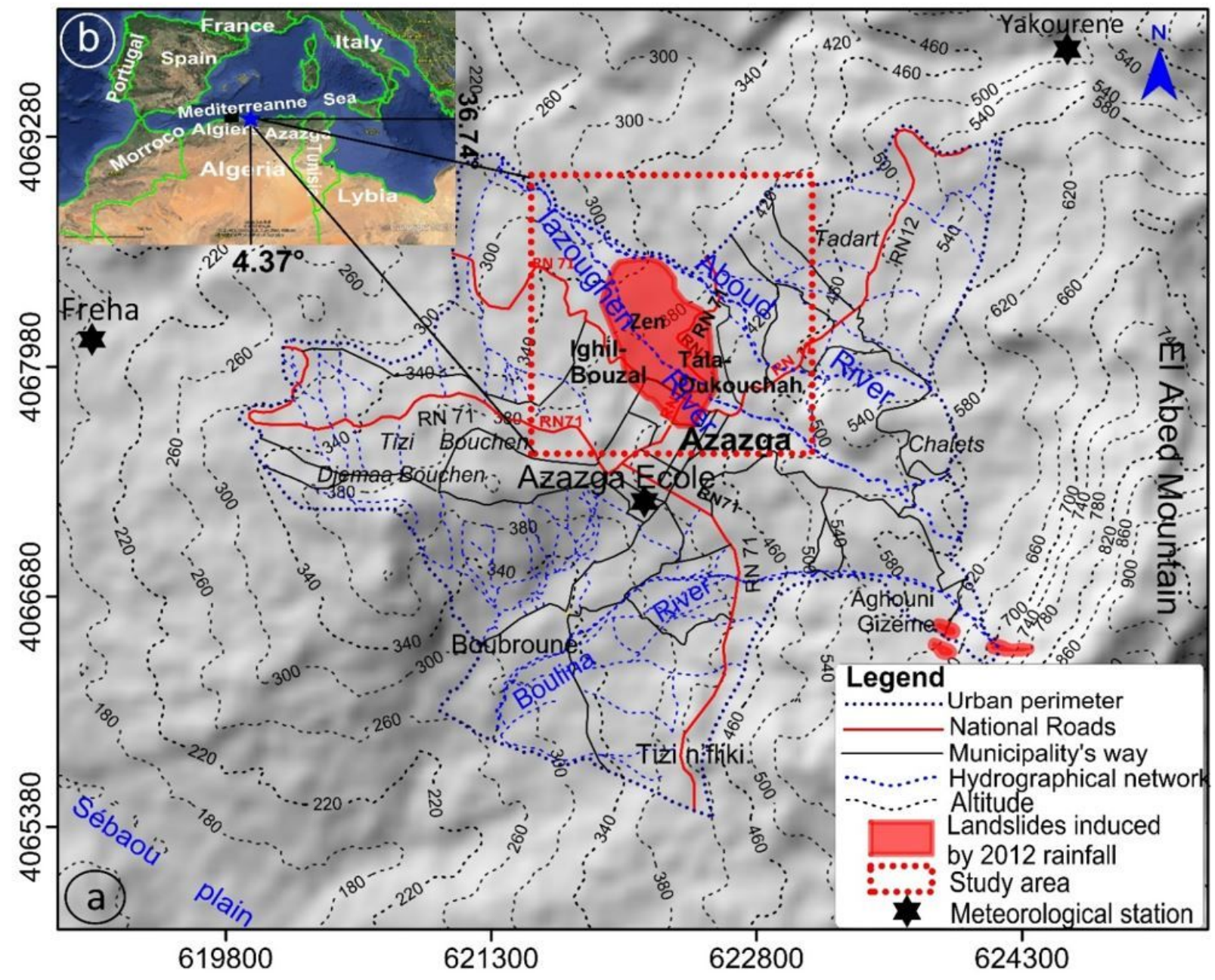

Figure 2

Geographical setting of the study area within: a) the north center of Algeria and at East of the capital city Algiers; b) administrative limit of the urban perimeter of the city of Azazga and spatial distribution of landslides induced by the 12 March 2012 rainfall event on the digital elevation model (DEM). Note: The designations employed and the presentation of the material on this map do not imply the expression of any opinion whatsoever on the part of Research Square concerning the legal status of any country, territory, city or area or of its authorities, or concerning the delimitation of its frontiers or boundaries. This map has been provided by the authors. 


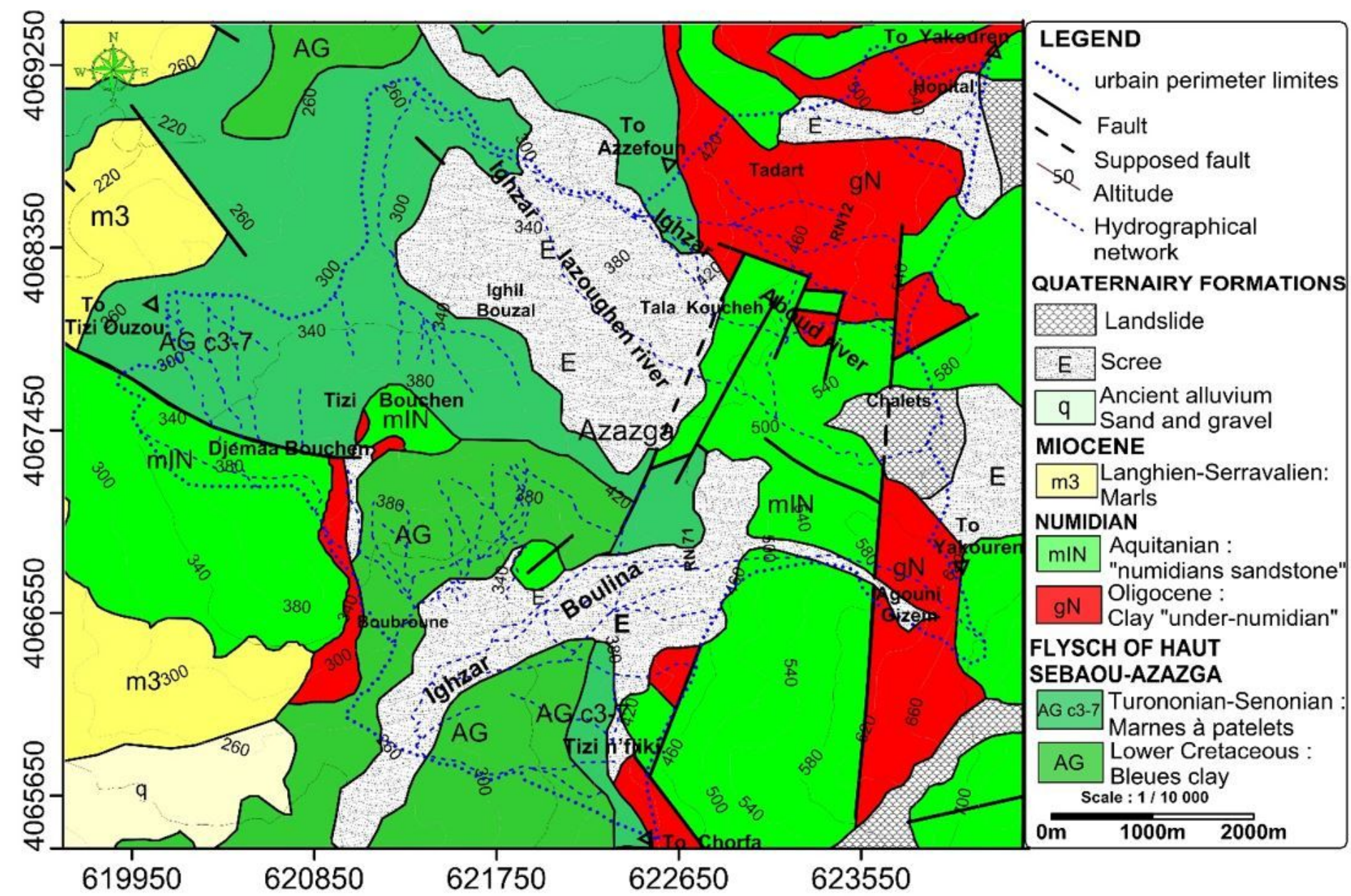

Figure 3

Geological map of the studied area (Gelard, 1979; ORGM, 1997) Note: The designations employed and the presentation of the material on this map do not imply the expression of any opinion whatsoever on the part of Research Square concerning the legal status of any country, territory, city or area or of its authorities, or concerning the delimitation of its frontiers or boundaries. This map has been provided by the authors. 


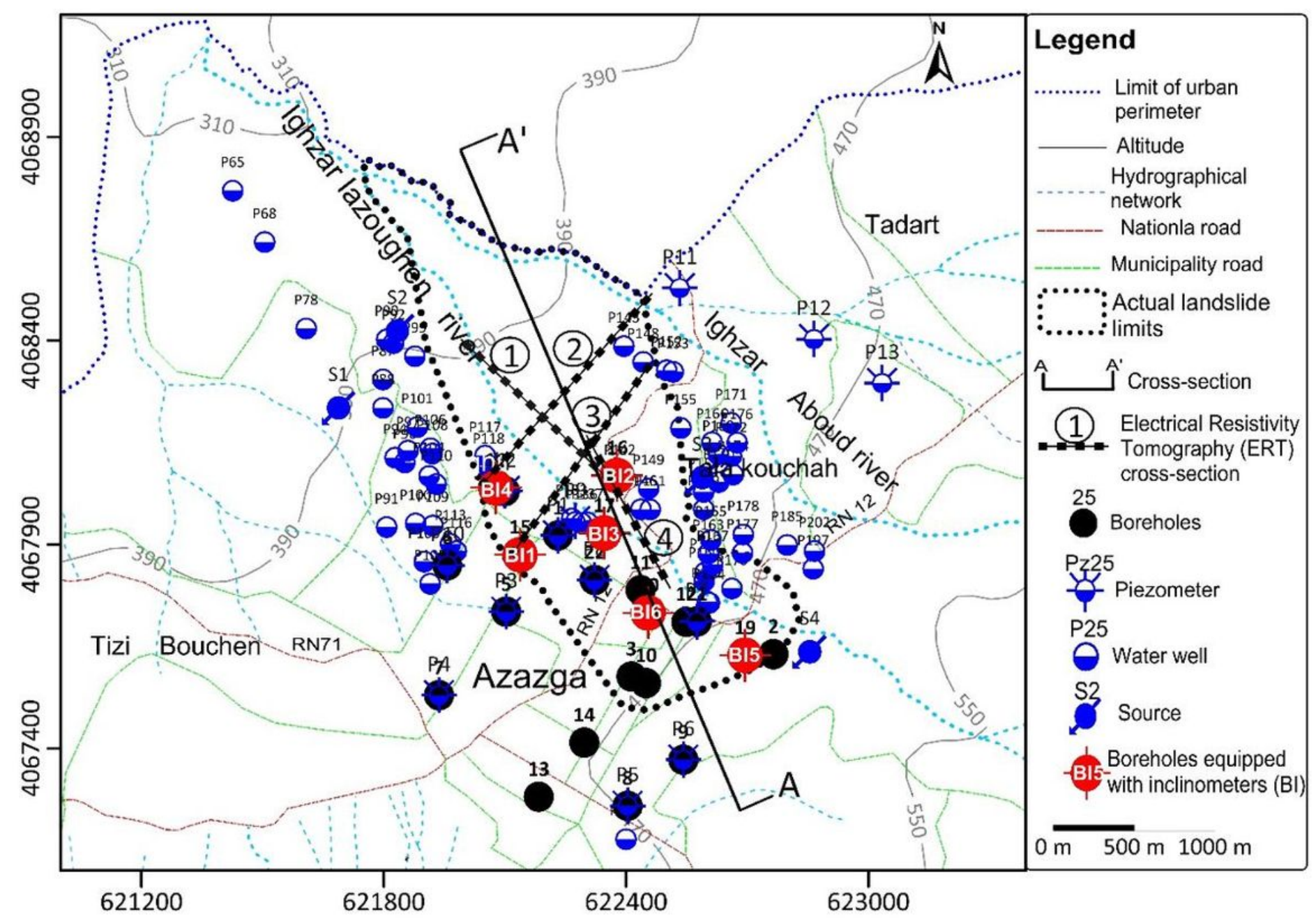

Figure 4

The location of boreholes, inclinometers, water points, cross-sections and ERT profiles. Note: The designations employed and the presentation of the material on this map do not imply the expression of any opinion whatsoever on the part of Research Square concerning the legal status of any country, territory, city or area or of its authorities, or concerning the delimitation of its frontiers or boundaries. This map has been provided by the authors. 


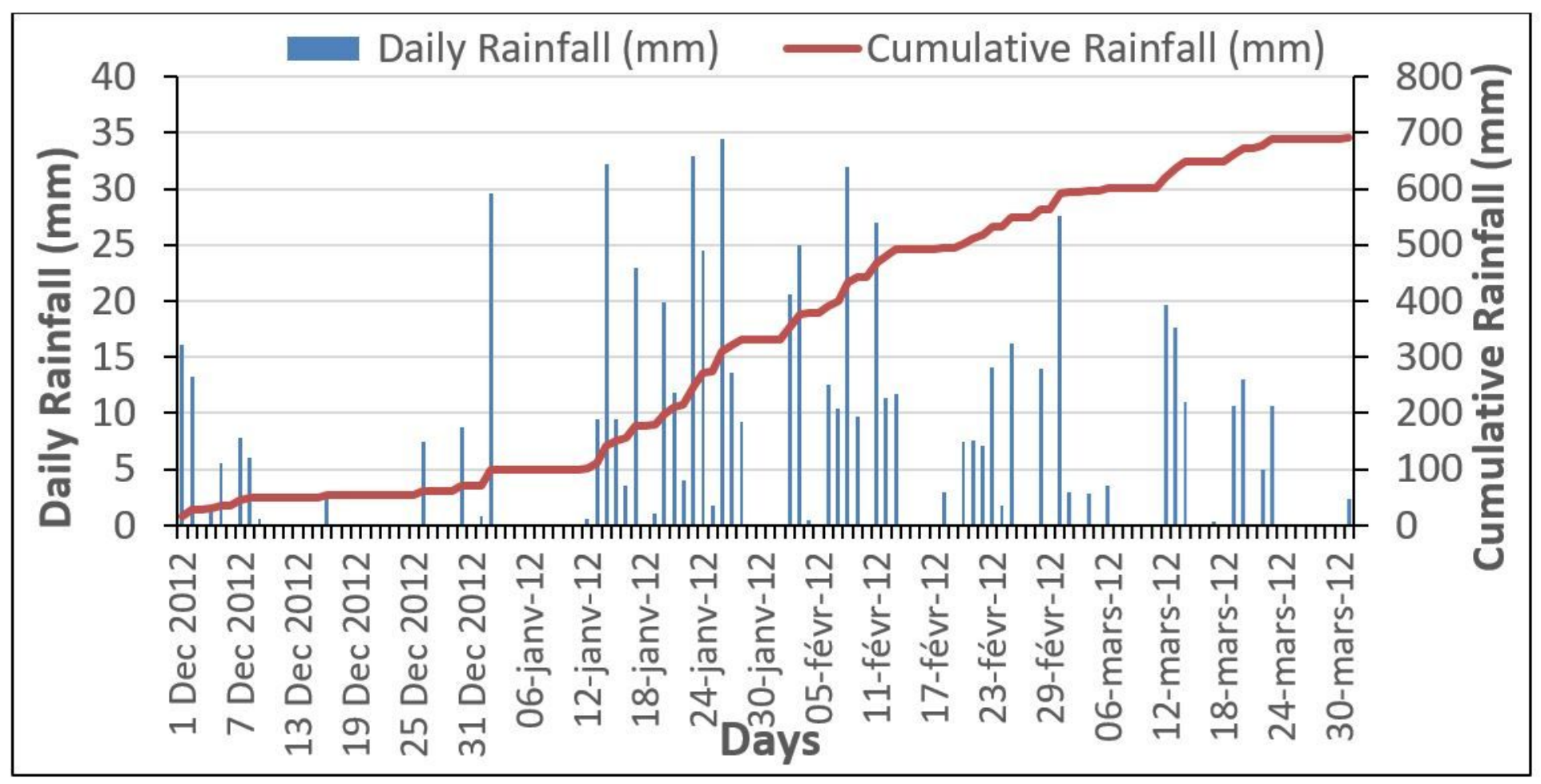

Figure 5

Distribution of daily average and cumulative rainfall from December 1 to March 30 recorded for the 2012 in Azazga city.

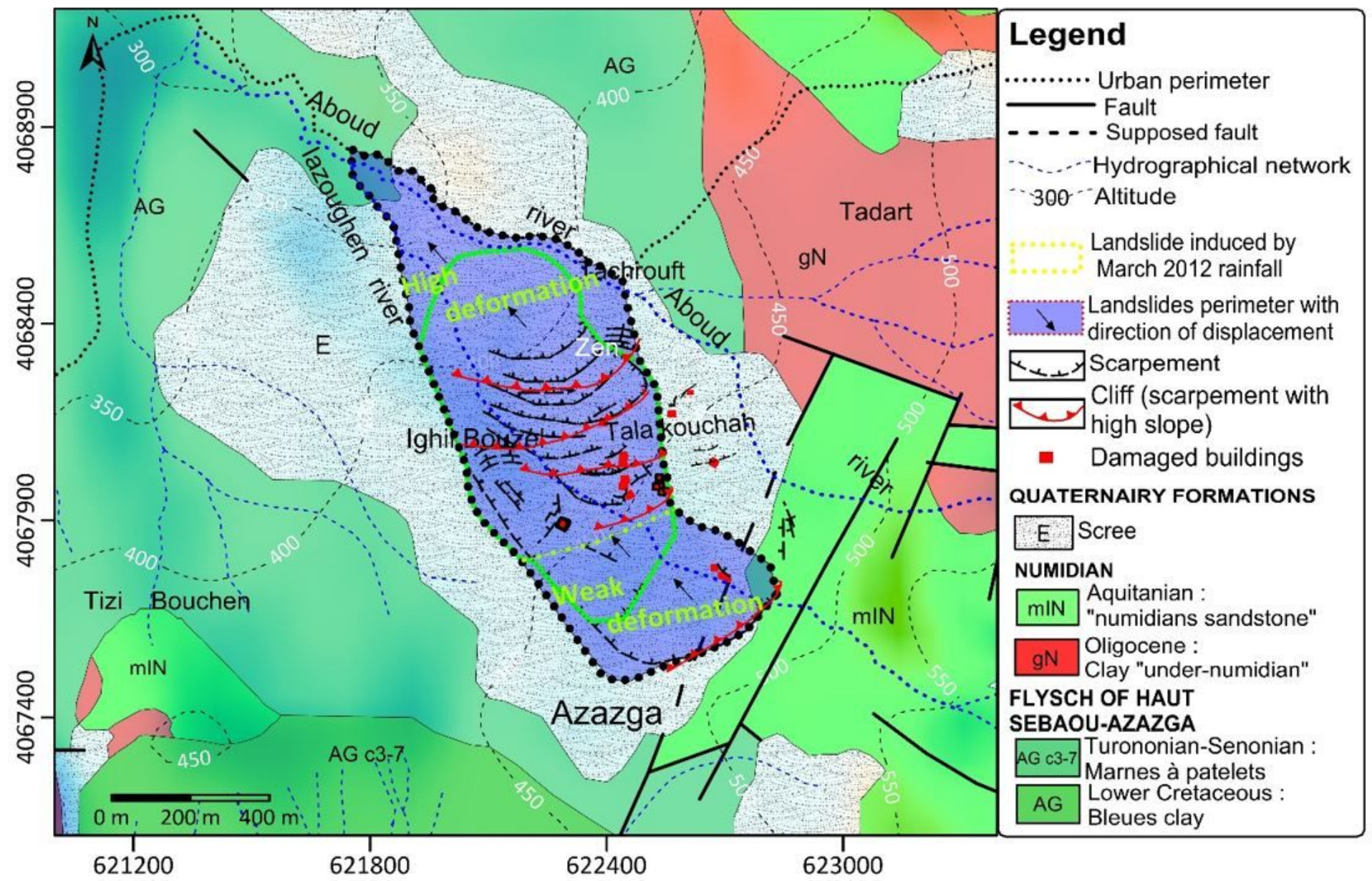

Figure 6 
Landslide inventory map of the study area based on aerial photographs/satellite images interpretation and field surveys, showing landslides distribution based on field surveys carried out immediately after the rainfall event of February 2010; and old landslide identified from photo-interpretation and field surveys. Note: The designations employed and the presentation of the material on this map do not imply the expression of any opinion whatsoever on the part of Research Square concerning the legal status of any country, territory, city or area or of its authorities, or concerning the delimitation of its frontiers or boundaries. This map has been provided by the authors.

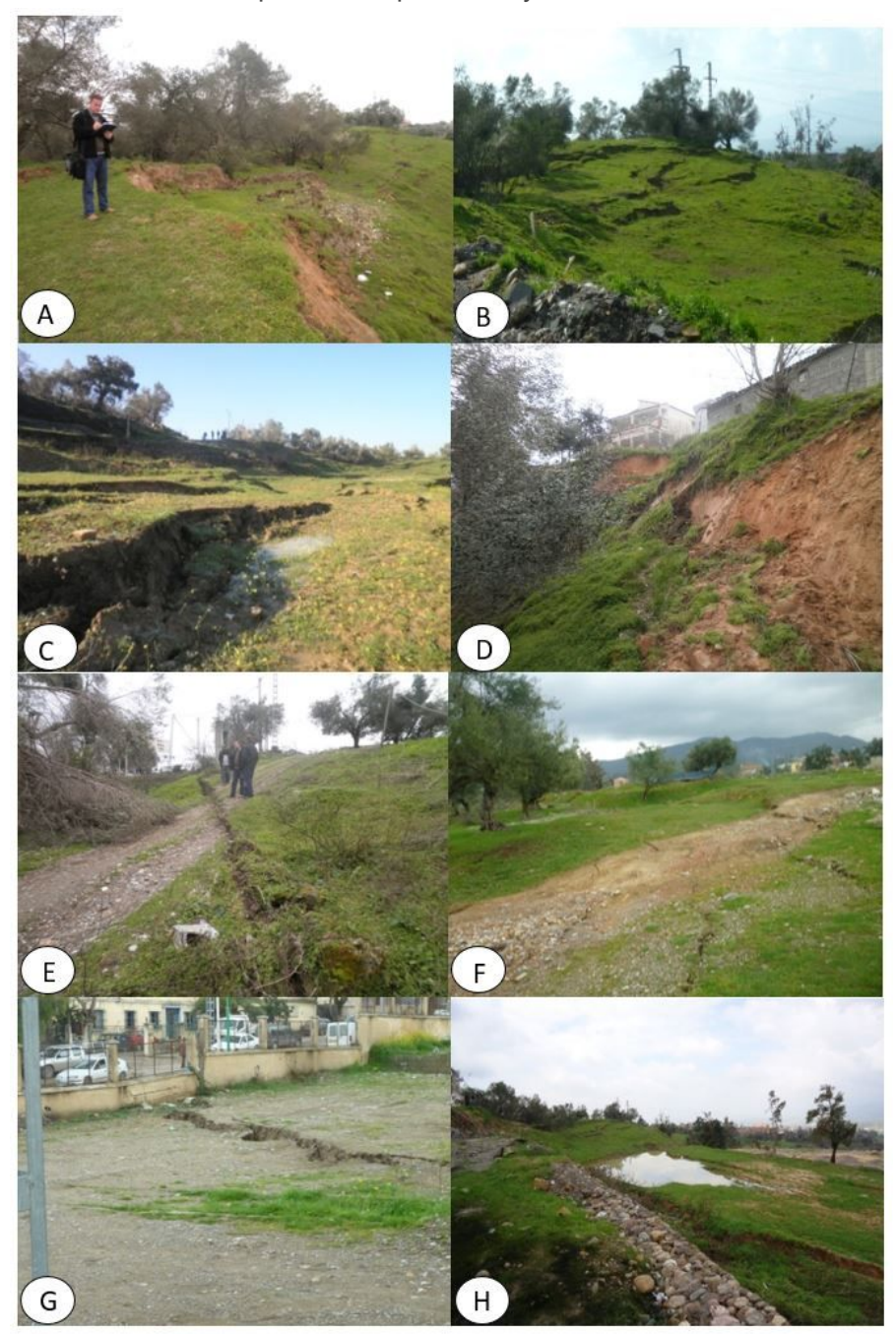

Figure 7

Photographs taken by the authors showing the landslides deformation characteristics observed following heavy rainfall of 2012 in the vicinity of Ighil Bouzel (northern of Azazga city). A, B and C) scarps with an arched shape located at the medium section of the landslide body in the district of Tala Oukouchah) banks on banks sliding in the district of Zen D) Main scarp, E, F and G) transverse cracks located within the moving masses in the district of Ighil- Bouzel and $\mathrm{H})$ Deformations and stagnation of rainwater at the toe of the landslide along the Ighil Bouzel slope. The locations of the photos taken (A-H) are shown on figure 10 . 


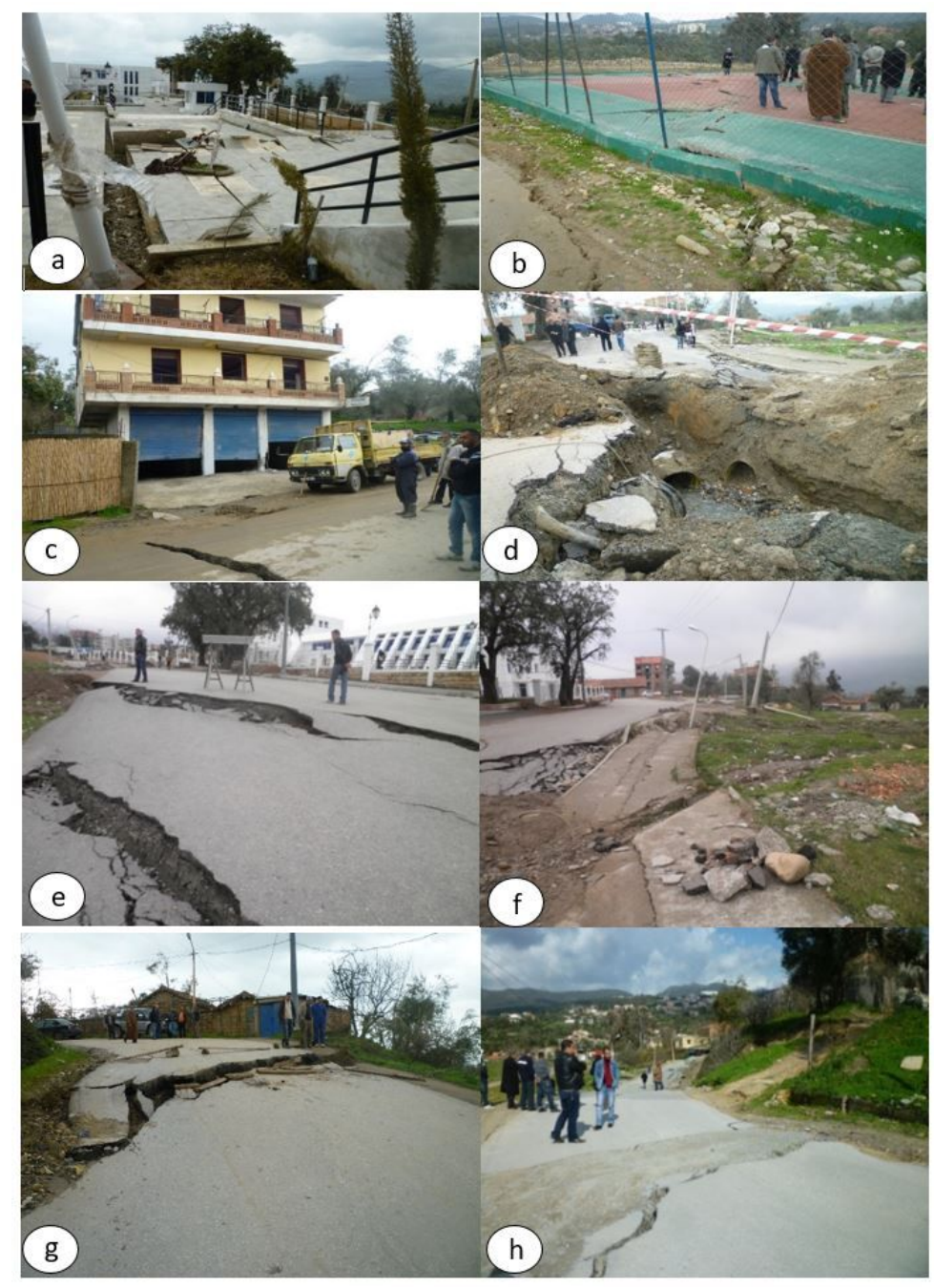

\section{Figure 8}

Photographs taken by the authors showing the landslide damages of buildings and roads occurred during the March 2012 rainfall event in the area under investigation: a) Main scarp and damage to the yard of the cultural centre in Ighil Bouzel b) Damage to a stadium in front of the cultural centre in Ighil Bouzel c) Severely damaged recent private house and the national road RN72 leading to Azzeffoun d) Damage to the pipes in front of the cultural centre, e and f) Damage to the road leading to Ighil Bouzel, $g$ and $h$ ) medium section of the landslide body in Tala Oukouchah with damage to the RN72 leading to Azzeffoun. The locations of the photographs (a-h) are shown on figure 10. 


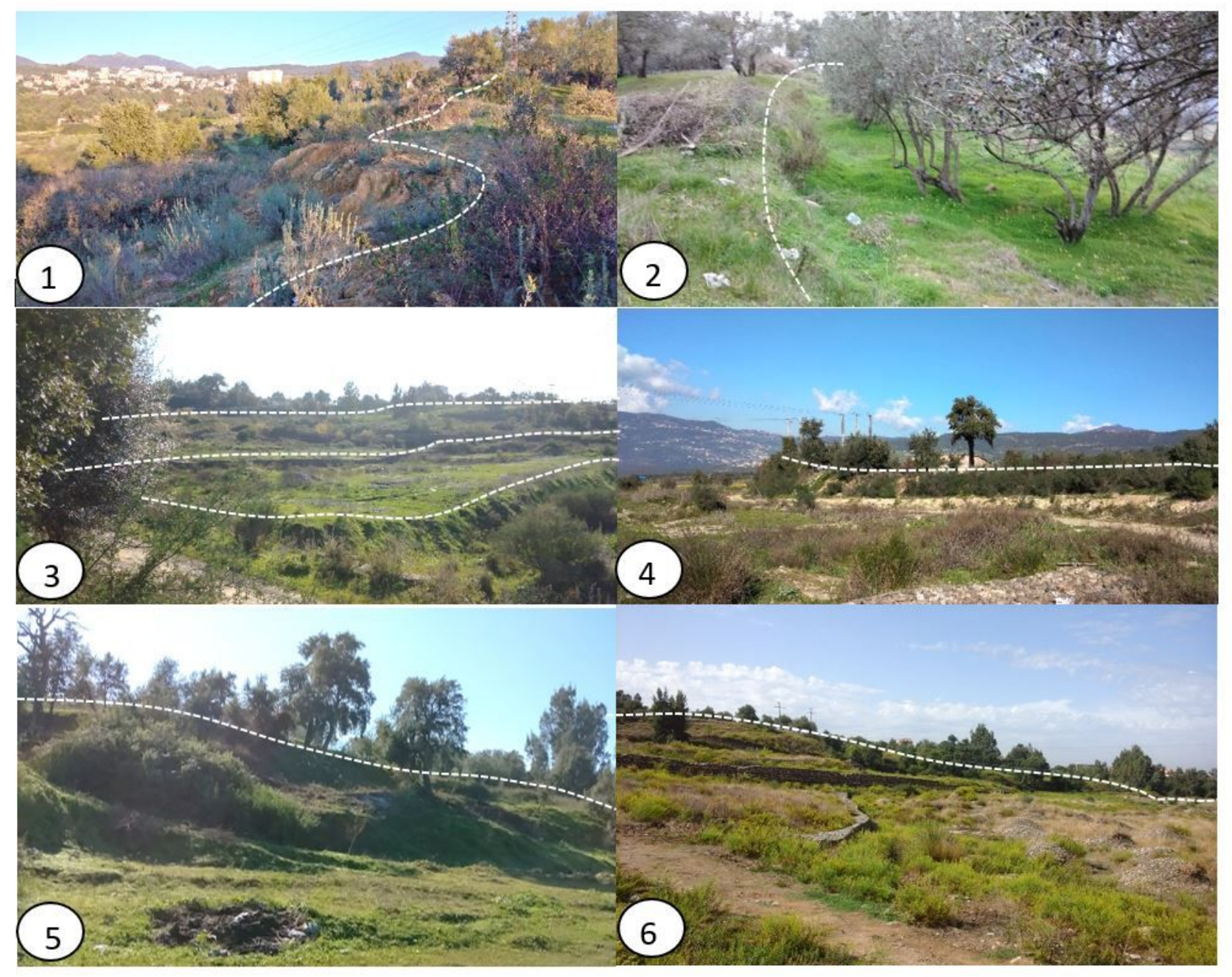

\section{Figure 9}

Examples on observations of ancient land instabilities indicating a mottled morphology with a series of bulges and long cliff-like scarps parallel to the general slope, counter slopes, old scars, characteristic of low stability slopes in the study area. The locations of the photographs (1-6) are shown on figure 10. 


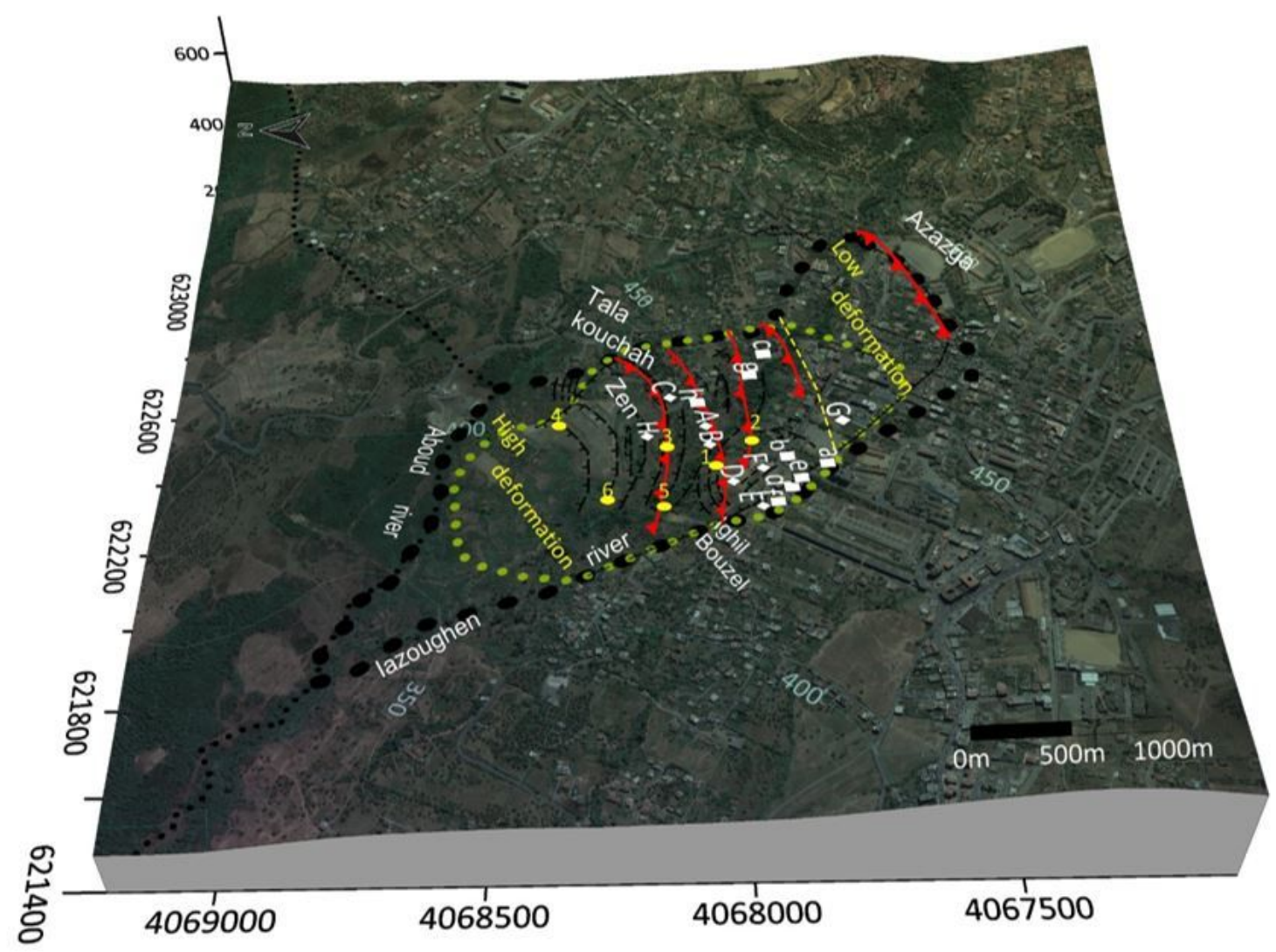

\section{Figure 10}

Digital elevation model showing a mottled morphology of slopes stability Distribution of landslides during the March 21 th, 2012 rainfall event in the study area. Letters $(a-h),(A-H)$ and numeration (1-6) indicate the localization of photographs of figures 7, 8, 9 and 10. Black points correspond to urban perimeter limits, black dotted points are extend of old landslides perimeter, yellow dotted points are landslides perimeter induced by March 2012 rainfall, black lines are scarps observed after March rainfall event, red lines are the long cliff-like scarps. Note: The designations employed and the presentation of the material on this map do not imply the expression of any opinion whatsoever on the part of Research Square concerning the legal status of any country, territory, city or area or of its authorities, or concerning the delimitation of its frontiers or boundaries. This map has been provided by the authors. Note: The designations employed and the presentation of the material on this map do not imply the expression of any opinion whatsoever on the part of Research Square concerning the legal status of any country, territory, city or area or of its authorities, or concerning the delimitation of its frontiers or boundaries. This map has been provided by the authors. 


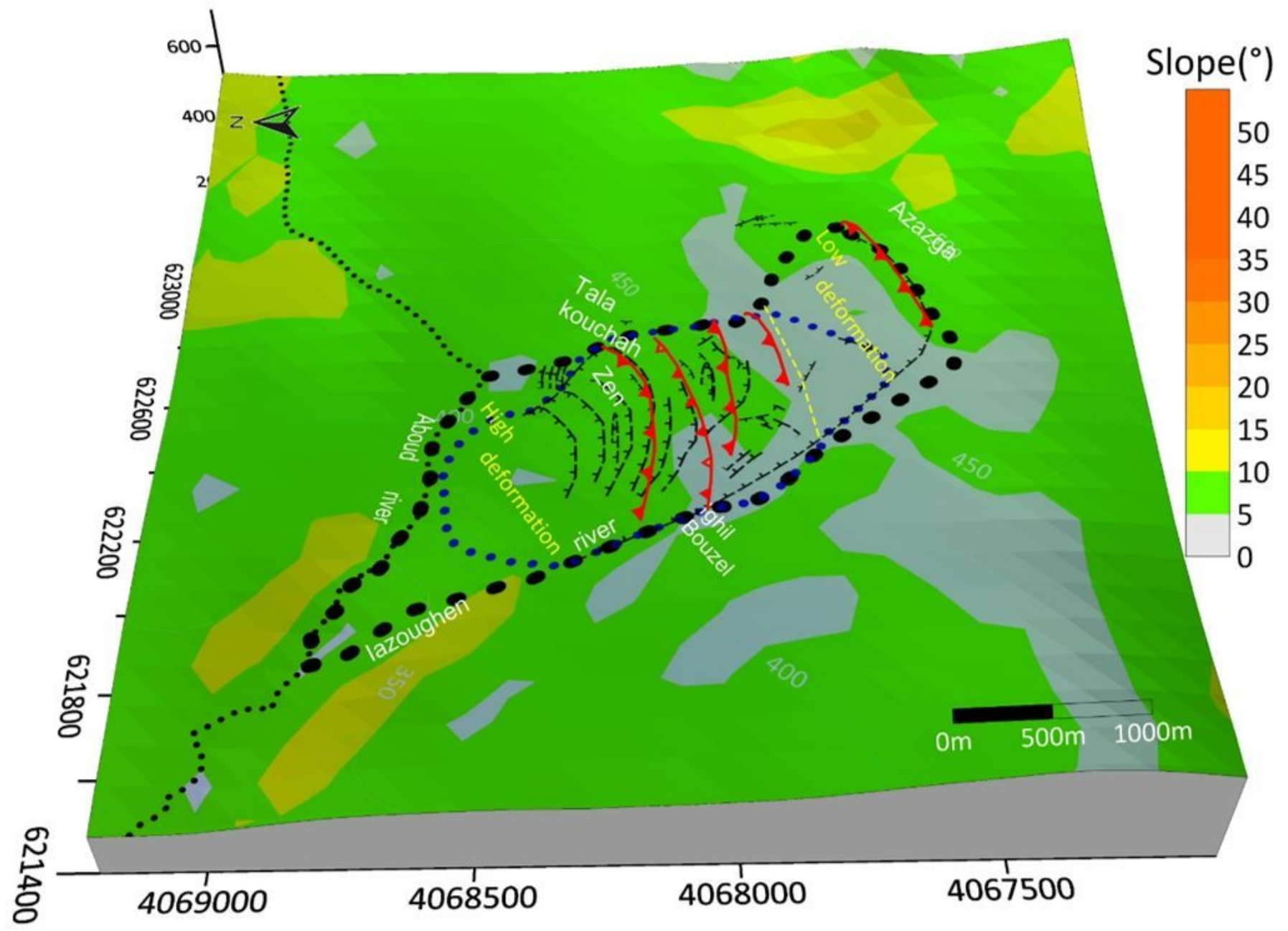

Figure 11

Local geomorphology on Digital elevation model with slope gradient classes. Black points correspond to urban perimeter limits, black dotted points are extend of old landslides perimeter, yellow dotted points are landslides perimeter induced by March 2012 rainfall, black lines are scarps observed after March rainfall event, red lines are the long cliff-like scarps. Note: The designations employed and the presentation of the material on this map do not imply the expression of any opinion whatsoever on the part of Research Square concerning the legal status of any country, territory, city or area or of its authorities, or concerning the delimitation of its frontiers or boundaries. This map has been provided by the authors. 


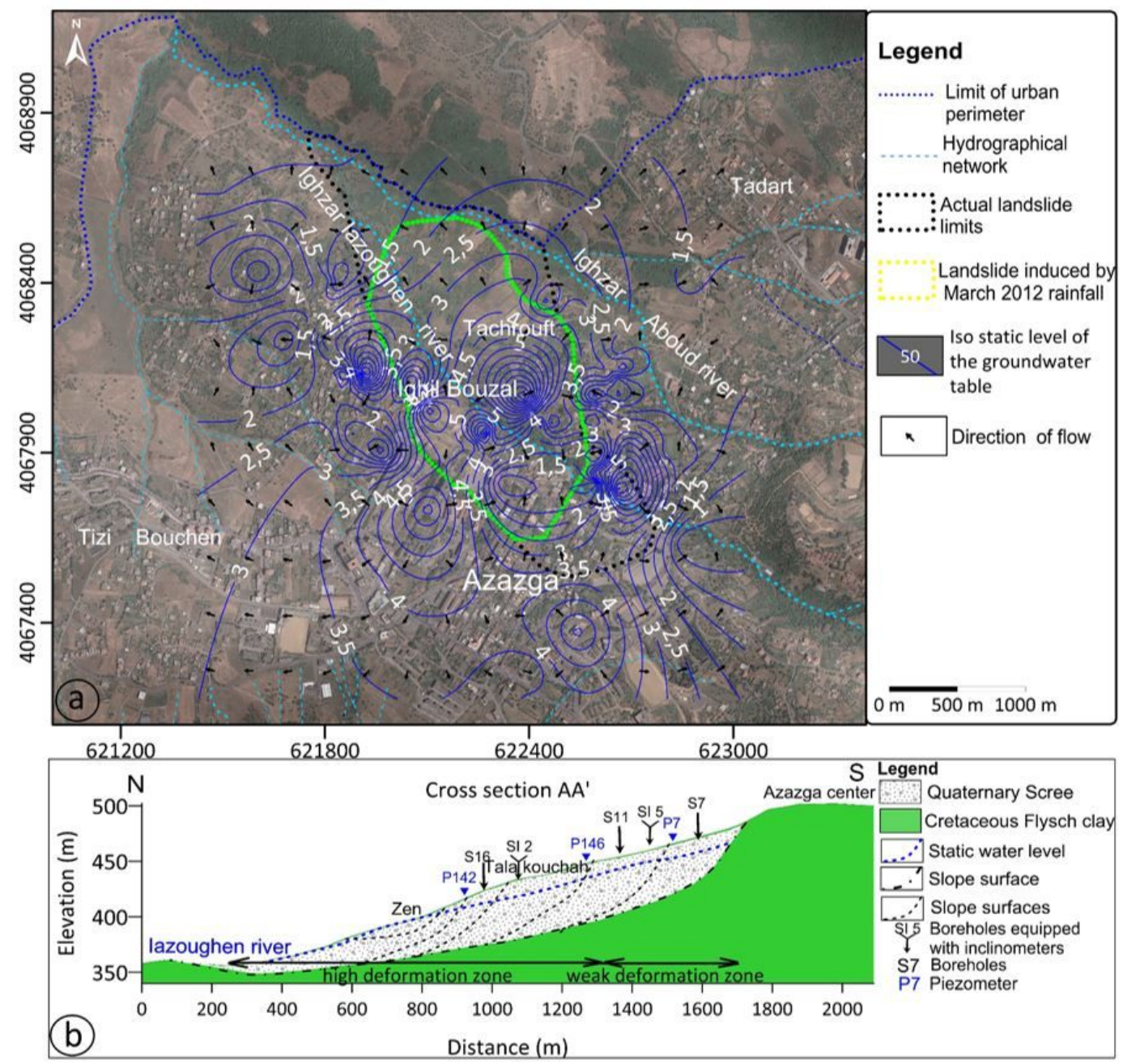

\section{Figure 12}

Hydrology and hydrogeology conditions of the study area: a) Static level (SL) map of the groundwater table in study area, b) Hydrogeological cross section of the landslide area (see figure 4 for the locations of the cross section) in North-south direction performed from Borehole, piezometer and inclinometer illustrating the lithological structure with static water level and probable slide surfaces in the studied area. Note: The designations employed and the presentation of the material on this map do not imply the expression of any opinion whatsoever on the part of Research Square concerning the legal status of any country, territory, city or area or of its authorities, or concerning the delimitation of its frontiers or boundaries. This map has been provided by the authors. 


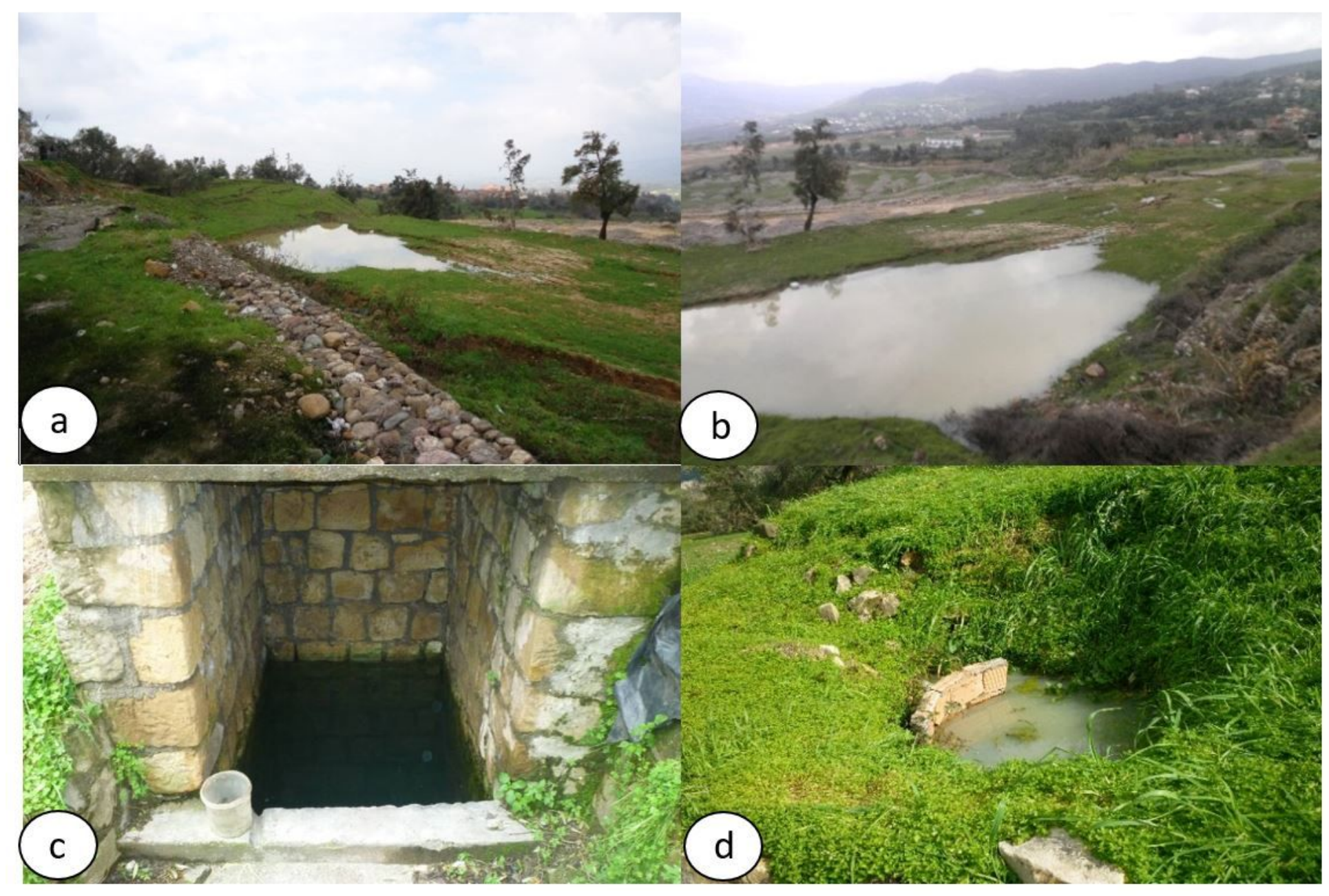

\section{Figure 13}

Observed of groundwater table in study area: $a$ and b) Groundwater discharge at the landslide toe after the 12 th March 2012 rainfall event, c and d) Wells and water spring showing the surface water level during wet periods in the downstream part of the landslide. 


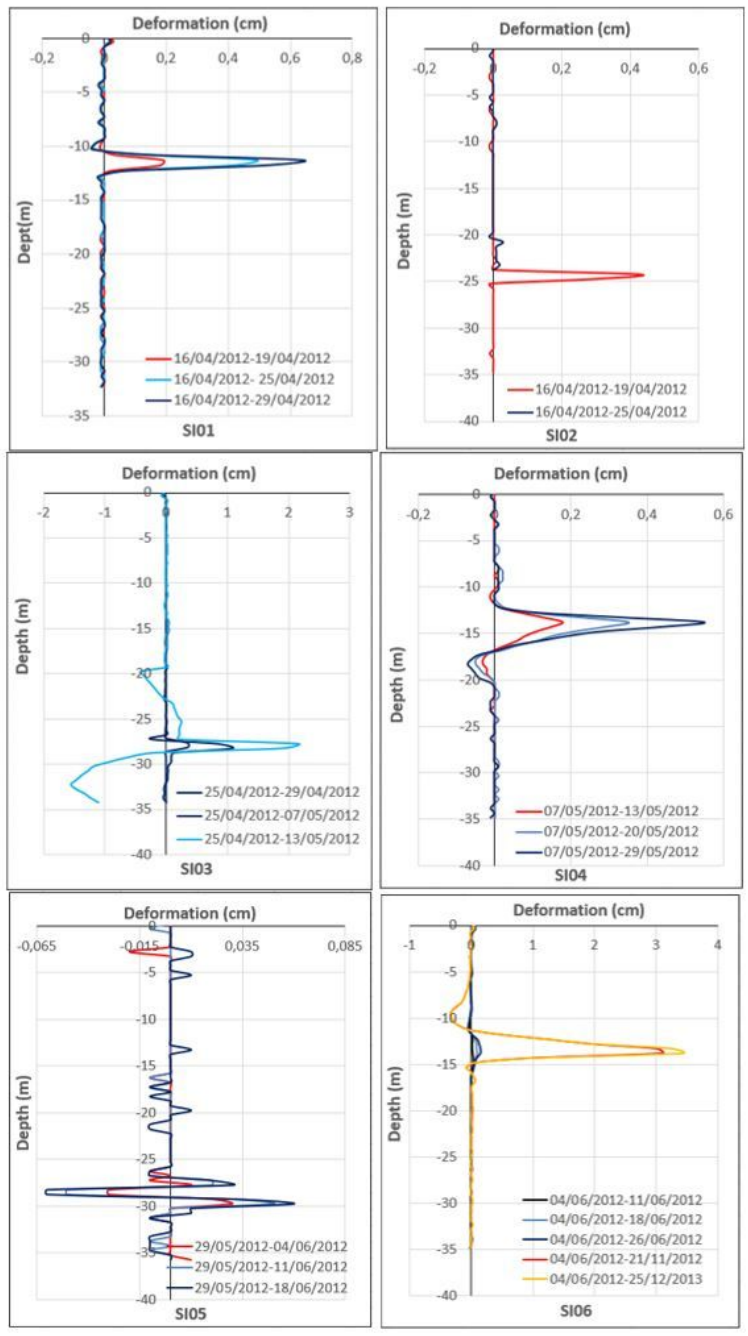

\section{Figure 14}

Historical displacement monitoring data from different inclinometers in the Tala- Oukouchah slope 


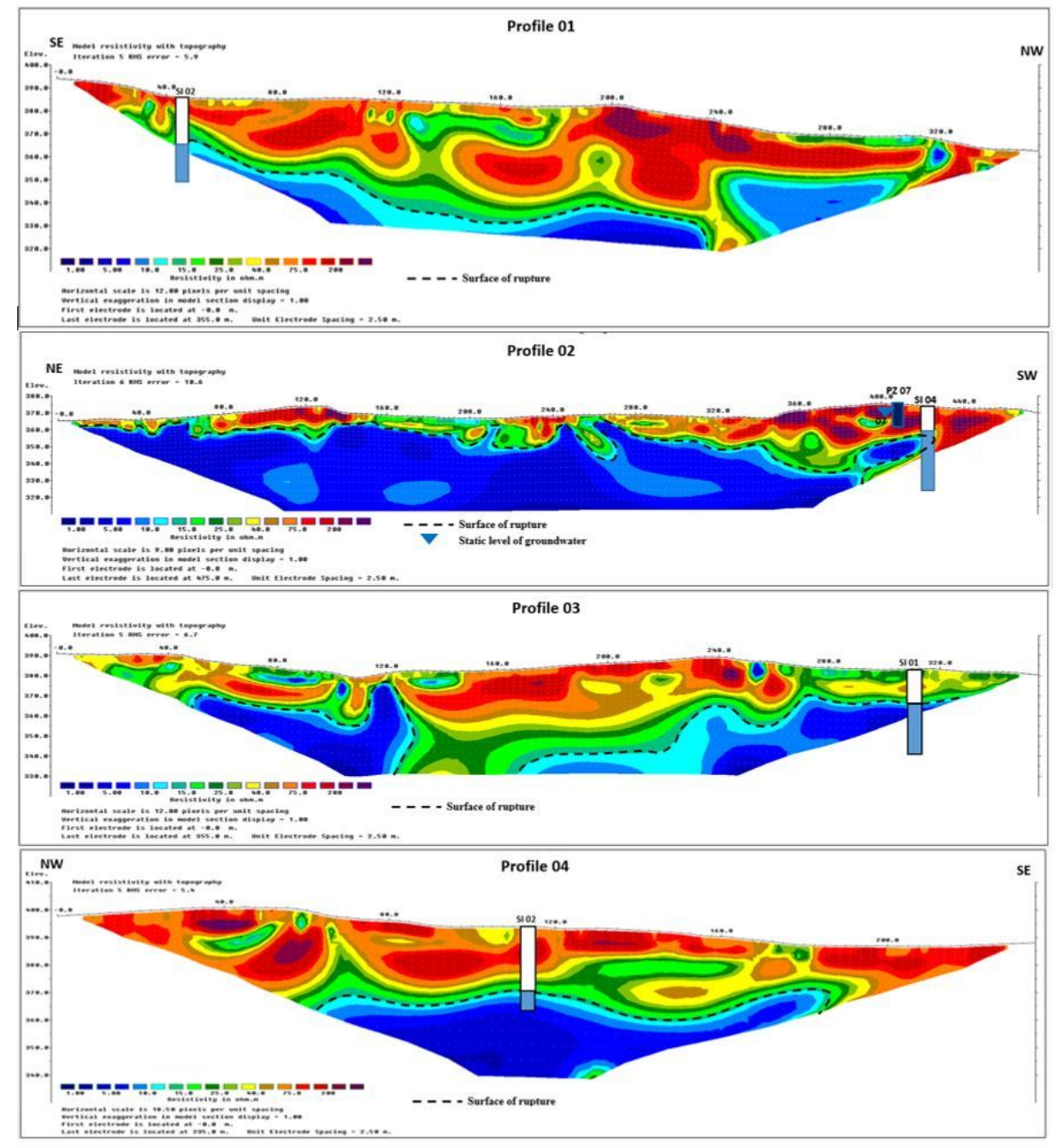

\section{Figure 15}

Electrical resistivity tomography results: profile 1 and profile 4 obtained along the direction of landslide movement, Profile 2 and Profile 3 along the perpendicular direction to the landslide movement (for location, see figure 4). 